\title{
REVIEW
}

\section{The interaction of carbon-centered radicals with copper(I) and copper(II) complexes $^{1}$}

\author{
THOMAS G. RIBELLI $\uparrow$, KRZYSZTOF MATYJASZEWSKI $\dagger$ and RINALDO \\ POLI*+
}

\author{
$\dagger$ Department of Chemistry, Carnegie Mellon University, 4400 Fifth Avenue, Pittsburgh, PA \\ 15213, United States of America \\ \$ LCC-CNRS, Université de Toulouse, CNRS, INPT, 205 Route de Narbonne, BP 44099, F- \\ 31077, Toulouse Cedex 4, France, and Institut Universitaire de France, 1, rue Descartes, 75231 \\ Paris Cedex 05, France
}

(received ....)

\begin{abstract}
Although alkylcopper(I) reagents are widespread, compounds containing alkyl ligands on $\mathrm{Cu}^{\mathrm{II}}$ or $\mathrm{Cu}^{\mathrm{III}}$ are much less common. Such complexes, however, are generated as transient species when carbon-center radicals add to $\mathrm{Cu}^{\mathrm{I}}$ or $\mathrm{Cu}^{\mathrm{II}}$ complexes, respectively, and appear to be involved in several copper-catalyzed organic transformations. A few organocopper(II) and organocopper(III) complexes were found sufficiently robust to allow isolation and full characterization. This article reviews the reactivity of carbon-centered radicals with $\mathrm{Cu}^{\mathrm{I}}$ and $\mathrm{Cu}^{\mathrm{II}}$ ions, both in aqueous and non-aqueous environments, with focus on the importance of the resulting organocopper species on atom transfer radical polymerization and on copper-catalyzed radical termination.
\end{abstract}

Keywords: Radicals; Copper; Metal-mediated radical polymerization; Catalyzed radical termination.

\section{A. Introduction}

Organometallic copper chemistry is widely developed when the metal has the formal oxidation state +1 and does not involve carbon-centered radicals [1-4]. The organocopper(I) species are

\footnotetext{
${ }^{1}$ Dedicated to Dan Meyerstein on the occasion of his 80th birthday.
} 
generated by nucleophilic routes and their bonds are homolytically strong, hence they generally do not produce radicals by homolytic cleavage. Conversely, organocopper(II) and -copper(III) derivatives contain weaker $\mathrm{Cu}-\mathrm{C}$ bonds and are much more rare. They may be generated by the interaction of carbon-centered radicals with $\mathrm{Cu}^{\mathrm{I}}$ and $\mathrm{Cu}^{\mathrm{II}}$ complexes, respectively, and often react by producing radicals. The combination of carbon-centered radicals and copper is attracting growing attention in organic synthesis for transformations such as alkylations [5] including trifluoromethylations [6], atom transfer radical additions (ATRA) [7, 8] and cyclizations [9], C-H bond oxidative functionalizations [10, 11] including fluorinations [12], and alkene difunctionalizations [13], to name just a few examples. Carbon-centered radicals that may be generated in the presence of copper complexes are also relevant in biochemistry [14-17]. Of even greater interest to us, copper is the champion, in terms of flexibility, ease of implementation and large-scale production potential, as metal mediator for the controlled polymerization of a wide variety of monomers by the radical mechanism known as atom transfer radical polymerization (ATRP) [18]. The role of copper in this process is to establish an equilibrium based on the transfer of a halogen atom (or a pseudo-halogen atom or group) $\mathrm{X}$, which relates the redox pair of $\mathrm{L} / \mathrm{Cu}^{\mathrm{I}}$ and $\mathrm{L} / \mathrm{Cu}^{\mathrm{II}}-\mathrm{X}$ with that of the $\mathrm{R}$ radical and the $\mathrm{R}-\mathrm{X}$ dormant species, see Scheme 1 . Through this equilibrated inner-sphere electron transfer (ISET) process, the metal complex installs a moderating effect on the free radical concentration that disfavors bimolecular radical terminations and favors reversible trapping to generate the stable dormant species $\mathrm{R}-\mathrm{X}$, also known as "persistent radical effect" [19]. This type of moderating equilibrium is just one example of the reversible termination strategy for "reversible deactivation radical polymerization" (RDRP-RT). Thus, in this process, as well as in several of the above-mentioned copper-catalyzed organic reactions, copper is able to generate a carbon-centered radical from a dormant species but does not directly interact with this radical to make an organocopper(II) species.

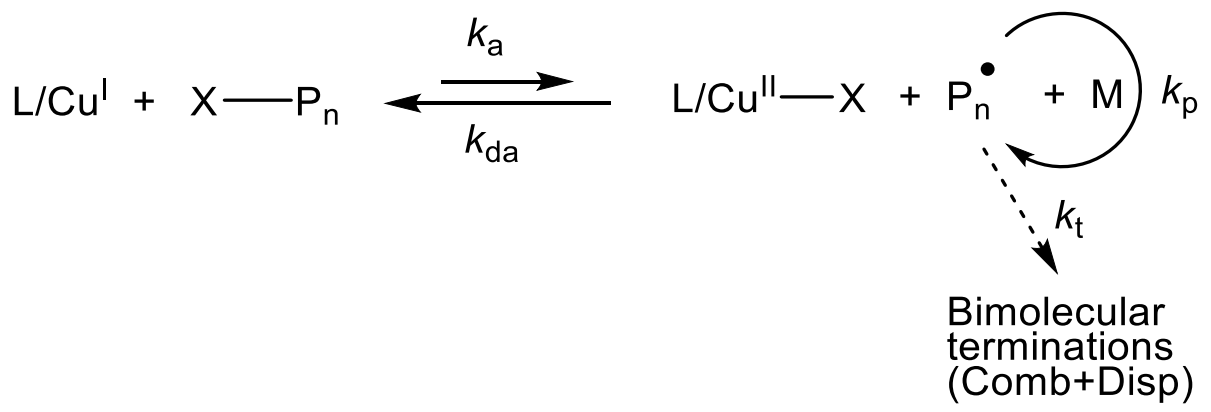

Scheme 1. Moderating equilibrium in Cu-catalyzed ATRP. The L/ symbol represents a generic coordination sphere around the metal center.

Yet, the interaction of carbon-centered radicals with transition metal complexes is an important phenomenon, both in organic synthesis and for another type of RDRP-RT process, known as organometallic-mediated radical polymerization (OMRP) [20, 21], which rests on the moderating equilibrium of Scheme 2. OMRP is another successful RDRP-RT strategy, particularly for certain "less-activated monomers", especially when using one of a variety of $\mathrm{L} / \mathrm{Co}{ }^{\mathrm{II}}$ complexes $[22,23]$. 


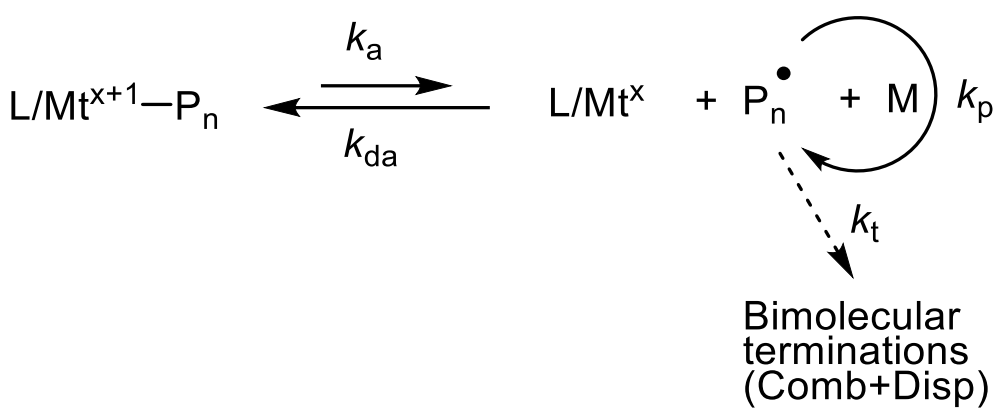

Scheme 2. Moderating equilibrium in an OMRP process. Mt is a generic metal and $\mathrm{x} / \mathrm{x}+1$ are its formal oxidation states.

The interaction of carbon-centered radicals with $\mathrm{L} / \mathrm{Cu}^{\mathrm{I}}$ complexes to yield organocopper(II) derivatives (or with $\mathrm{L} / \mathrm{Cu}^{\mathrm{II}}$ complexes to yield organocopper(III) derivatives) is not generally invoked in ATRP systems. However, growing evidence has recently shown that direct radicalcopper interactions play an important role.

Carbon-centered radicals $\mathrm{R}$ react in many ways, including bimolecular annihilation by coupling and/or disproportionation, by group elimination, by atom abstraction and by addition to unsaturated functions. Of specific relevance to the current review, they can add to other atoms or groups X that contain one or more unpaired electrons, including transition metals, to establish an R-X bond. The reactivity is generally correlated with the strength of the bond formed when $\mathrm{X}$ is the $\mathrm{H}$ atom. Radicals based on an $s p$ or $s p^{2}$ hybridized $\mathrm{C}$ atom (e.g. alkynyl, vinyl, phenyl) are more reactive than those based on an $s p^{3}$ hybridized $\mathrm{C}$ atom and the reactivity of the latter is attenuated by hyperconjugation $\left(\mathrm{CH}_{3}>\right.$ primary $>$ secondary $>$ tertiary) and even more by delocalization (e.g. allyl, benzyl). Atoms or groups $\mathrm{X}$ different than $\mathrm{H}$ may also be used to evaluate the $\mathrm{R}-\mathrm{X}$ bond dissociation energy, which is relevant to specific applications such as ATRP for $\mathrm{X}=$ halogen $(\mathrm{Cl}$, $\mathrm{Br}$ ) or nitroxide-mediated polymerization for $\mathrm{R}_{2} \mathrm{NO}$ radicals. The relative order of $\mathrm{R}-\mathrm{X}$ bond strengths roughly parallels the order of $\mathrm{R}-\mathrm{H}$ bond strengths, but is modulated by the nature of $\mathrm{X}$, notably the steric demand and by the R-X bond polarity [24].

The purpose of this article is to review the current literature knowledge on the interaction between copper complexes and carbon-centered radicals and on the stability and isolability of the resulting organocopper(II) and -(III) derivatives.

\section{B. Interaction with copper(II) complexes}

\section{B.1. General considerations}

The primary reaction of interest is the formation of a direct bond between the carbon-centered radical and the $\mathrm{Cu}^{\mathrm{II}}$ ion in $\left[\mathrm{L} / \mathrm{Cu}^{\mathrm{II}}\right]$ to form $\left[\mathrm{L} / \mathrm{Cu}{ }^{\mathrm{III}}-\mathrm{R}\right]$, see eq. (1). However, other modes of interaction between the radical and a $\mathrm{Cu}^{\mathrm{II}}$ complex, notably when the latter already contains an alkyl ligand, such as the [L/Cu$\left.{ }^{\mathrm{II}}-\mathrm{R}\right]$ systems that will be analyzed in section $\mathrm{C}$ (eq. (2)), will also be considered. We will not cover in detail the atom transfer process involved in ATRP deactivation (Scheme 1), as several other reviews devoted to this process are available [18, 25-30]. 


$$
\begin{aligned}
& \mathrm{R}^{\bullet}+\left[\mathrm{L} / \mathrm{Cu}^{\mathrm{II}}\right] \rightarrow\left[\mathrm{L} / \mathrm{Cu}{ }^{\mathrm{III}}-\mathrm{R}\right] \\
& \mathrm{R}^{\cdot}+\left[\mathrm{L} / \mathrm{Cu}^{\mathrm{II}}-\mathrm{R}^{\prime}\right] \rightarrow \text { products }
\end{aligned}
$$

The mode of decomposition and further reactivity of the organocopper(III) transient have been shown to follow several pathways, the main ones being shown in eq. (3)-(5) depending on the nature of $\mathrm{R}, \mathrm{L}$ and the presence of external reagents.

$$
\begin{aligned}
& {\left[\mathrm{L} / \mathrm{Cu}^{\mathrm{III}}-\mathrm{R}\right]+\mathrm{SH} \rightarrow\left[\mathrm{L} / \mathrm{Cu}^{\mathrm{I}}\right]+\mathrm{SR}+\mathrm{H}^{+}} \\
& {\left[\mathrm{L} / \mathrm{Cu}^{\mathrm{III}}-\mathrm{R}\right] \rightarrow\left[\mathrm{L} / \mathrm{Cu}^{\mathrm{I}}\right]+\mathrm{R}^{(-\mathrm{H})}+\mathrm{H}^{+}} \\
& {\left[\mathrm{L} / \mathrm{Cu}^{\mathrm{III}}-\mathrm{R}\right]+\mathrm{H}_{2} \mathrm{O} \rightarrow\left[\mathrm{L} / \mathrm{Cu}^{\mathrm{III}}\right]+\mathrm{RH}+\mathrm{OH}^{-}}
\end{aligned}
$$$$
\text { oxidative solvolysis }
$$

$\beta$-H oxidation

protonolysis

The existence of organocopper(III) transients was first proposed by Kochi [31] for the copperbased oxidation of alkyl radicals. Such radicals (e.g. n-butyl, isopropyl, neopentyl) were generated in acetic acid/acetonitrile solution according to eq. (6) and then further oxidized by copper(II) ions to give alkene products. This transformation was proposed to occur by decomposition of the organocopper(III) intermediate via eq. (4). It was later found that the rate of this reaction is enhanced in the presence of non-coordinating anions for $\mathrm{Cu}^{\mathrm{II}}$ [32]. The study revealed that the ratelimiting step for oxidation precedes and is separate from the product-forming step, requiring the formation of an unobserved intermediate. Walling invoked organocopper(III) transients to rationalize the effect of copper ions on the oxidation of alcohols by the Fenton reagent [33].

$$
\mathrm{RCOO}-\mathrm{OOCR}+\left[\mathrm{L} / \mathrm{Cu}^{\mathrm{I}}\right] \rightarrow\left[\mathrm{L} / \mathrm{Cu}^{\mathrm{II}}(\mathrm{OOCR})\right]+\mathrm{CO}_{2}+\mathrm{R}^{\bullet}
$$

In subsequent work, it was shown that the interaction between radicals and $\mathrm{L} / \mathrm{Cu}{ }^{\mathrm{II}}$ compounds proceeds via two competing pathways: direct atom transfer, ISET (path $a$ in Scheme 3), which is the basis of ATRA and ATRP, and a second pathway named oxidative substitution, via the organocopper(III) intermediate (path $b$ in Scheme 3). The second step of path $b$ involves heterolysis of the $\mathrm{L} / \mathrm{Cu}^{\mathrm{III}}-\mathrm{R}$ bond to produce carbocations, as suggested by the observation of polar solvent effects, by the analysis of structural rearrangements and by the results of H/D isotope labelling experiments [34]. The atom transfer pathway usually represents the major course of the reaction, with the alternative pathway becoming preferred only for alkyl radicals capable of forming stabilized carbenium ions. The ratio between the two pathways is somewhat influenced by the copper coordination sphere. These dichotomy was also observed later in ATRP [35, 36]. 


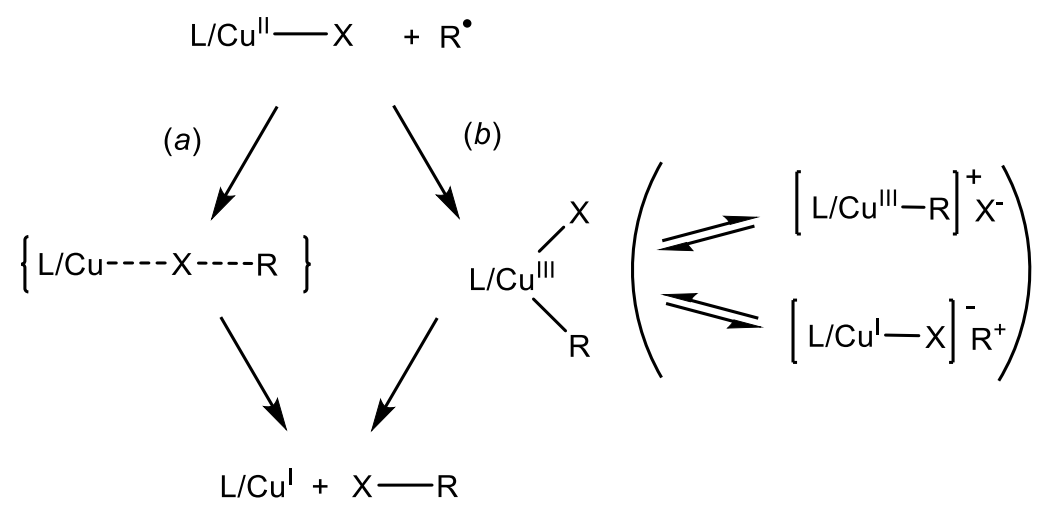

Scheme 3. Competing pathways in the interaction between carbon-centered radicals and copper(II).

It is worth mentioning here that organocopper(III) intermediates have also been postulated in the copper-catalyzed cross-coupling between Grignard reagents and alkyl halides, generated by oxidative addition of the alkyl halide to an organocopper(I) species and there is no evidence for alkyl radical involvement in this process [37].

\section{B.2. Reactions with $\mathrm{Cu}^{2+}{ }_{\mathrm{aq}}$}

The first spectroscopic evidence for the existence of the postulated organocopper(III) intermediates was provided by the laboratory of Dan Meyerstein, to whom this review article is dedicated. The general method of producing carbon-centered radicals by this group was pulse radiolysis (repeated short irradiations with high-energy electrons) of aqueous solutions, hence in this case $\mathrm{L} / \mathrm{is}$ equivalent to $\left(\mathrm{H}_{2} \mathrm{O}\right)_{\mathrm{n}}$. This treatment generates a host of reactive species $\left(\mathrm{e}^{-}{ }_{\mathrm{aq}}, \mathrm{HO}^{*}, \mathrm{H}^{*}, \mathrm{H}_{2}, \mathrm{H}_{2} \mathrm{O}_{2}\right.$, $\mathrm{H}_{3} \mathrm{O}^{+}{ }_{\text {aq }}$ ), most of which are quenched by additives such as $\mathrm{N}_{2} \mathrm{O}$ to yield $\mathrm{HO}^{\circ}$ selectively. The latter is then able, in the presence of various additives, to produce carbon-centered radicals. For instance, the ${ }^{\circ} \mathrm{CH}_{2} \mathrm{CO}_{2}{ }^{-}$radical anion is generated in the presence of acetate ions. Freiberg and Meyerstein applied this procedure in the presence of $\mathrm{CuSO}_{4}$ to generate an unstable $\left[\mathrm{L} / \mathrm{Cu}^{\mathrm{III}} \mathrm{CH}_{2} \mathrm{CO}_{2}\right]^{+}$ intermediate with a first-order rate law both in $\mathrm{Cu}^{2+}$ and ${ }^{\circ} \mathrm{CH}_{2} \mathrm{CO}_{2}{ }^{-}$and a rate constant $k$ in the range (4.8 - 7.6) $10^{8} \mathrm{M}^{-1} \mathrm{~s}^{-1}$, depending on the solution ionic strength [38]. The key to the observation of this species is the peculiar nature of this radical, whereas other $\mathrm{Cu}^{\mathrm{III}}-\mathrm{R}$ intermediates generated by pulse radiolysis studies with other radicals are too short-lived for observation $[39,40]$. The transient $\mathrm{L} / \mathrm{Cu}^{\mathrm{III}}\left(\mathrm{CH}_{2} \mathrm{CO}_{2}\right)^{+}$species is characterized by an absorption band with a maximum at ca. $350 \mathrm{~nm}$ and decays by two independent first order laws with rate constants of $(90 \pm 5) \mathrm{s}^{-1}$ and $(2.8 \pm 0.3) \mathrm{s}^{-}$ ${ }^{1}$, which were interpreted as a decarboxylation of the acetate adduct (eq. (7)) and the solvolytic oxidation (eq. (3), $\mathrm{SH}=\mathrm{H}_{2} \mathrm{O}$ ). It was mentioned in that study that the same radicals are also able to interact with $\mathrm{Cu}^{+}$aq, but more detailed investigations of that process were only reported later (see section C). Indeed, the pulse radiolysis study of how carbon-centered radicals interact with $\mathrm{Cu}^{2+}{ }_{\text {aq }}$ ions is complicated by the subsequent interaction of the radicals with $\mathrm{Cu}^{+}{ }_{\text {aq }}$, which is generated by the transient decomposition (e.g. eq. (3) and (4)). Thus, the study provides useful information only if the primary $\left[\mathrm{Cu}^{\mathrm{III}}-\mathrm{R}\right]_{\mathrm{aq}}$ product is long-lived and if it forms rapidly, relatively to other secondary reaction. This is the reason, for instance, why the simple ${ }^{\circ} \mathrm{CH}_{3}$ radical was not investigated by this method in the early reports, since its reaction with $\mathrm{Cu}^{2+}{ }_{\text {aq }}$ is slow (vide infra), while the 
corresponding addition to $\mathrm{Cu}^{+}{ }_{\text {aq }}$ is much faster [41]. This problem is also present for the addition of radicals to $\mathrm{Cu}^{\mathrm{II}}$ complexes with other coordination spheres.

$$
\left[\left(\mathrm{MeCO}_{2}\right) \mathrm{Cu}^{\mathrm{III}}-\mathrm{CH}_{2} \mathrm{CO}_{2}\right]_{\mathrm{aq}} \rightarrow\left[\mathrm{Cu}^{\mathrm{II}}-\mathrm{CH}_{2} \mathrm{CO}_{2}\right]_{\mathrm{aq}}+\mathrm{CO}_{2}+\mathrm{Me}^{\bullet}
$$

In later contributions, the two groups of Buxton [42] and Meyerstein [43] independently analyzed the interaction of aqueous solutions of $\mathrm{Cu}^{2+}{ }_{\text {aq }}$ with other radicals $\left({ }^{\circ} \mathrm{CHMeCO}{ }_{2}^{-},{ }^{\circ} \mathrm{CH} \mathrm{CO}_{2}{ }^{-}\right.$ ) $\mathrm{CH}(\mathrm{OH}) \mathrm{CO}_{2}{ }^{-},{ }^{\circ} \mathrm{CCl}_{3},{ }^{\circ} \mathrm{CH}_{2} \mathrm{CH}_{2} \mathrm{OH},{ }^{\circ} \mathrm{CH}_{2} \mathrm{CMe}_{2} \mathrm{OH},{ }^{\circ} \mathrm{CMe} 2 \mathrm{OH},{ }^{\circ} \mathrm{CHMeOH}$ and ${ }^{\circ} \mathrm{CH}_{2} \mathrm{OH}$ ), which were generated by pulse radiolysis in the presence of suitable $\mathrm{R}-\mathrm{H}$ substrates (propionate, fumarate, chloroform, ethylene, tert-butanol, isopropanol, ethanol, and methanol). These investigations confirmed that when the free radicals $\mathrm{R}^{\cdot}$ are easily oxidized (e.g. ${ }^{\circ} \mathrm{CR}_{1} \mathrm{R}_{2} \mathrm{OH},{ }^{\circ} \mathrm{CCl}_{3}$ ) the lifetime of the $\left[\mathrm{Cu}^{\mathrm{III}}-\mathrm{R}\right]_{\mathrm{aq}}$ species is too short for observation under the experimental conditions employed, but ${ }^{\circ} \mathrm{CH}_{2} \mathrm{CH}_{2} \mathrm{OH}$ and ${ }^{\circ} \mathrm{CH}_{2} \mathrm{CMe}_{2} \mathrm{OH}$ gave observable transients. Because of the formation of $\mathrm{Cu}^{+}{ }_{\text {aq }}$, the results are complicated by the subsequent formation of $\left[\mathrm{Cu}^{\mathrm{II}}-\mathrm{R}\right]_{\text {aq }}$ derivatives, as will be detailed in the next section. However, the first order dependence on $\left[\mathrm{Cu}^{2+}\right]$ and $\left[\mathrm{R}^{\circ}\right]$ for the formation reaction was confirmed, with a rate constant that depends on the nature of the radical: electron withdrawing groups (i.e. $-\mathrm{CH}_{2} \mathrm{OH},-\mathrm{Cl},-\mathrm{OH},-\mathrm{CO}_{2}^{-}$) increase the rate of $\mathrm{Cu}^{\mathrm{III}}-\mathrm{R}$ formation, with fine tuning provided by the charge and spin density delocalization in the radical. The reactions led to decomposition products by first order processes according to the stoichiometries of eq. (3) (HS = protic solvent) or (4), depending on the nature of the radical.

For the pulse radiolysis experiment carried out in the presence of methanol, Johnson later showed that the $\mathrm{MeOH}$ and $\mathrm{Cu}^{2+}$ aq substrates compete for the primary $\mathrm{H}^{\cdot}$ radical [44], the former to generate the ${ }^{\circ} \mathrm{CH}_{2} \mathrm{OH}$ radical as reported in the previous study by Buxton [42], the latter to generate $\mathrm{Cu}^{+}$aq and $\mathrm{H}^{+}$. While ${ }^{\circ} \mathrm{CH}_{2} \mathrm{OH}$ is then oxidized to formaldehyde via the proposed $\left[\mathrm{Cu}^{\mathrm{III}}-\mathrm{CH}_{2} \mathrm{OH}\right]^{2+}{ }_{\text {aq }}$ ion according to equation (4), $\mathrm{Cu}^{+}$aq is reoxidized by a second $\mathrm{H}^{\bullet}$ equivalent to yield $\mathrm{Cu}^{2+}$ aq and $\mathrm{H}_{2}$.

A slightly different outcome results from the pulse radiolysis study of $\mathrm{Cu}^{2+}{ }_{\text {aq }}$ in the presence of $\mathrm{Me}_{3} \mathrm{CCOOH}$, which generates the ${ }^{\circ} \mathrm{CH}_{2} \mathrm{CMe}_{2} \mathrm{COOH}$ radical [45]. The $\left[\mathrm{Cu}^{\mathrm{III}}-\mathrm{CH}_{2} \mathrm{CMe}_{2} \mathrm{COOH}\right]^{2+}{ }_{\text {aq }}$ product is generated with similar kinetics and spectroscopic properties to the above-described related processes, but decomposes with a much slower rate, $k=(0.03 \pm 0.01) \mathrm{s}^{-1}$. For instance, the decomposition rate constants for $\left[\mathrm{Cu}^{\mathrm{III}}-\mathrm{CH}_{2} \mathrm{COOH}\right]^{2+}$ aq and $\left[\mathrm{Cu}^{\mathrm{III}}-\mathrm{CH}_{2} \mathrm{CMe}_{2} \mathrm{OH}\right]^{2+}$ aq are $2.8 \mathrm{~s}^{-1}$ and $4.5 \cdot 10^{2} \mathrm{~s}^{-1}$, respectively. This result was rationalized by a proposed stabilization of the organocopper(III) transient by chelation through the carbonyl $\mathrm{O}$ atom to make a 5-member cycle. In addition, whereas $\left[\mathrm{Cu}^{\mathrm{III}}-\mathrm{CH}_{2} \mathrm{COOH}\right]^{2+}{ }_{\text {aq }}$ and $\left[\mathrm{Cu}^{\mathrm{III}}-\mathrm{CH}_{2} \mathrm{CMe}_{2} \mathrm{OH}\right]^{2+}{ }_{\text {aq }}$ decompose according to eq. 6, $\left[\mathrm{Cu}^{\mathrm{III}}-\mathrm{CH}_{2} \mathrm{CMe}_{2} \mathrm{COOH}\right]^{2+}{ }_{\text {aq }}$ yields different products, see eq. (8).

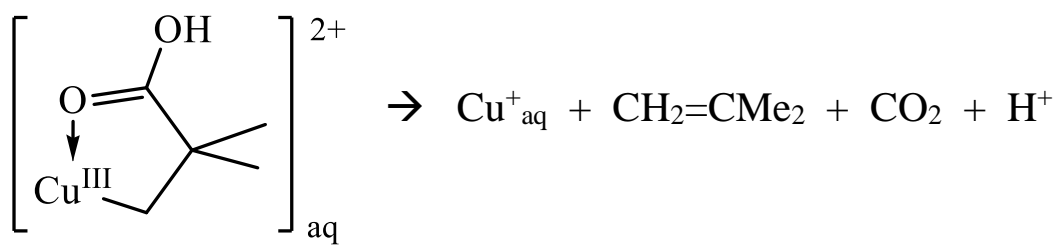


In a subsequent contribution, the Meyerstein group described the reaction between $\mathrm{Cu}^{2+}{ }_{\text {aq }}$ (and also $\mathrm{Cu}^{+}$aq, see section $\mathrm{C}$ ) with the ${ }^{\circ} \mathrm{CH}_{2} \mathrm{CMe}\left(\mathrm{NH}_{3}{ }^{+}\right) \mathrm{COO}^{-}$radical produced by pulse radiolysis in the presence of 2-methylalanine [46]. The generated $\left[\mathrm{Cu}^{\mathrm{III}}-\mathrm{CH}_{2} \mathrm{CMe}\left(\mathrm{NH}_{3}{ }^{+}\right)\left(\mathrm{COO}^{-}\right)\right]^{2+}$ transient $(k=$ $(1.3 \pm 0.3) \cdot 10^{7} \mathrm{M}^{-1} \mathrm{~s}^{-1}$ ) was found to first rearrange by a $\mathrm{pH}$-dependent first order process $(k$ in the $5-50 \mathrm{~s}^{-1}$ range) to a different species with a very similar absorption spectrum. Then, a second slower first order decay ( $k$ in the $0.08-0.15 \mathrm{~s}^{-1}$ range) leads to the generation of $\mathrm{CO}_{2}$ and acetone in equal yields, plus $\mathrm{Cu}^{+}$aq. This result was interpreted on the basis of the same process illustrated in eq. (8), where $\mathrm{CO}_{2}$ is eliminated with formation of a proposed $\mathrm{CH}_{2}=\mathrm{CMe}\left(\mathrm{NH}_{3}{ }^{+}\right)$intermediate, which would then hydrolyze rapidly to liberate ammonia and the enol tautomer of acetone. A 5-membered intermediate rationalizes, also in this case, the relatively long lifetime of this transient.

Carbon-centered radicals have also been generated in situ more directly by photochemical methods and their interaction with copper ions has been widely studied. Methyl radicals were generated by flash irradiations of $\left[\mathrm{Co}\left(\mathrm{NH}_{3}\right)_{5}\left(\mathrm{OCOCH}_{3}\right)\right]^{2+}$, eq. (9), and intercepted with $\mathrm{Cu}^{2+}{ }_{\text {aq }}$ ions to yield metastable $\left[\mathrm{Cu}^{\mathrm{III}} \mathrm{CH}_{3}\right]^{2+}{ }_{\text {aq }}$ with a first-order dependence on both $\left[\mathrm{Cu}^{2+}\right]$ and $\left[\mathrm{CH}_{3}{ }^{\circ}\right]$ and a rate constant $k=(7.4 \pm 0.6) \cdot 10^{5} \mathrm{M}^{-1} \mathrm{~s}^{-1}[47]$. The $\left[\mathrm{Cu}^{\mathrm{III}} \mathrm{CH}_{3}\right]^{2+}{ }_{\text {aq }}$ transient species was identified by an absorption with $\lambda_{\max }<350 \mathrm{~nm}$. Moreover, the decay of this species obeyed a first-order rate law with $\mathrm{k}=(7.2 \pm 0.3) \cdot 10^{2} \mathrm{~s}^{-1}$ to yield methanol by solvolytic oxidation (eq. (3)) and methane. The latter was proposed to result from radical reduction by the $\mathrm{Co}^{\mathrm{II}}$ photoproduct according to a previous report [48], eq. (10). In the same contribution, the observation of a saturation effect (accumulation of the photolysis products from repetitive flashes) on the kinetics led to the suggestion that $\mathrm{CH}_{3}{ }^{\cdot}$ is also trapped by $\mathrm{Cu}^{+}$, as will be further detailed in the section $\mathrm{C}$.

$$
\begin{aligned}
& {\left[\mathrm{Co}\left(\mathrm{NH}_{3}\right)_{5}\left(\mathrm{OCOCH}_{3}\right)\right]^{2+}+5 \mathrm{H}^{+} \stackrel{\mathrm{hv}}{\longrightarrow} \mathrm{Co}^{2+} \text { aq }+5 \mathrm{NH}_{4}{ }^{+}+\mathrm{CO}_{2}+\mathrm{CH}_{3}} \\
& \mathrm{CH}_{3}{ }^{\cdot}+\mathrm{H}^{+}+\mathrm{L} / \mathrm{Co}^{\mathrm{II}} \rightarrow \mathrm{CH}_{4}+\mathrm{L} / \mathrm{Co}^{\mathrm{III}}
\end{aligned}
$$

\section{B.3. Reactions with ligand-stabilized $\mathrm{Cu}^{\mathrm{II}}$ systems}

The reaction of carbon-centered radicals with $\mathrm{L} / \mathrm{Cu}{ }^{\mathrm{II}}$ complexes that contain a halide ligand, leading to halogen atom transfer, is quite common and relevant to ATRP (Scheme 1). As mentioned in the introduction, we will not cover this phenomenon in this review, focusing instead on the direct interaction between carbon-centered radicals and the $\mathrm{Cu}^{\mathrm{II}}$ metal center.

The addition of nitrilotriacetate, $\mathrm{N}\left(\mathrm{CH}_{2} \mathrm{CO}_{2}{ }^{-}\right)_{3}$ (nta) to the radiolysis solutions containing $\mathrm{Cu}^{2+}{ }_{\text {aq }}$ ions sufficiently stabilizes the organocopper(III) intermediates $\left[\left(\text { nta) } \mathrm{Cu}^{\mathrm{III}}-\mathrm{CR}_{1} \mathrm{R}_{2} \mathrm{OH}\right]^{-}\right.$to allow their observation [49], whereas this is not possible for the aqueous ion. These transients were obtained uncontaminated by $\left[(\mathrm{nta}) \mathrm{Cu}^{\mathrm{II}}-\mathrm{CR}_{1} \mathrm{R}_{2} \mathrm{OH}\right]^{2-}$ from $\mathrm{N}_{2} \mathrm{O}$-saturated solutions, whereas mixtures of $\mathrm{L} / \mathrm{Cu}^{\mathrm{III}}$ and $\mathrm{L} / \mathrm{Cu}^{\mathrm{II}}$ species resulted from the radiolysis of He-saturated solutions. The $\mathrm{L} / \mathrm{Cu}^{\mathrm{II}}$ species could not be studied in detail because they were always formed as mixtures with the $\mathrm{L} / \mathrm{Cu}^{\mathrm{III}}$ transients and both have similar lifetimes and spectra. Transients generated by addition of the ${ }^{\circ} \mathrm{CH}_{2} \mathrm{OH},{ }^{\circ} \mathrm{CHMeOH},{ }^{\circ} \mathrm{CMe}_{2} \mathrm{OH}$ and ${ }^{\circ} \mathrm{CH}_{3}$ radicals could be obtained. Except for the [(nta) $\mathrm{Cu}^{\text {III- }}$ $\left.\mathrm{CH}_{3}\right]^{-}$species, the decomposition of which obeys a first-order rate law, these species decay by a 
second-order rate law, indicating reduction of a second $\left[\mathrm{Cu}^{\mathrm{II}}(\mathrm{nta})\right]^{-}$complex (eq. (11), $\left.\mathrm{L}=\mathrm{nta}\right)$. The electron-donating power of the nta ligand protects the metal from internal reduction by the $\mathrm{Cu}-$ bonded radical and makes the species a stronger reductant. Other external oxidants are able to exert the same function as $\left[(\text { nta }) \mathrm{Cu}^{\mathrm{II}}\right]^{-}$.

$$
\left[\mathrm{L} / \mathrm{Cu}^{\mathrm{III}}-\mathrm{CR}_{1} \mathrm{R}_{2} \mathrm{OH}\right]+\left[\mathrm{L} / \mathrm{Cu}^{\mathrm{II}}\right] \rightarrow\left[\mathrm{L} / \mathrm{Cu}^{\mathrm{II}}\right]+\left[\mathrm{L} / \mathrm{Cu}^{\mathrm{I}}\right]+\mathrm{R}_{1} \mathrm{R}_{2} \mathrm{CO}+\mathrm{H}^{+}
$$

These results are relevant in biochemistry, as copper ions are known to sensitize radiation damage and ${ }^{\circ} \mathrm{OH}$ radicals are formed among other reactive oxygen species under oxidative stress conditions. These ${ }^{\circ} \mathrm{OH}$ radicals are likely to react with the organic compounds present in the biological media to create carbon-centered radicals, rather than directly with the copper ions. Thus, several studies were conducted on the interaction of radicals with model complexes of biological relevance. Using $\mathrm{Cu}^{\mathrm{II}}$ triglycine $\left(\mathrm{G}_{3}\right)$ [50] and tetraglycine $\left(\mathrm{G}_{4}\right)$ [51] adducts under physiological-to-slightly basic conditions gave evidence in favor of the formation of $\mathrm{Cu}^{\mathrm{III}}\left(\mathrm{G}_{\mathrm{n}}\right)$ species with $k>10^{8} \mathrm{M}^{-1} \mathrm{~s}^{-1}$ when the substrate solutions were subjected to pulse radiolysis in the presence of $\mathrm{NaBr}$ (which generates ${ }^{\circ} \mathrm{Br}_{2}{ }^{-}$), whereas the presence of $t \mathrm{BuOH}$ or $\mathrm{MeCOONa}$ (i.e. ${ }^{\circ} \mathrm{CH}_{2} \mathrm{CMe}_{2} \mathrm{OH}$ or ${ }^{\circ} \mathrm{CH}_{2} \mathrm{CO}_{2}{ }^{-}$radicals) led to the formation of other species described as $\left[\mathrm{L} / \mathrm{Cu}^{\mathrm{III}}-\mathrm{CH}_{2} \mathrm{CMe}_{2} \mathrm{OH}\right]$ or $\left[\mathrm{L} / \mathrm{Cu}^{\mathrm{III}}-\mathrm{CH}_{2} \mathrm{CO}_{2}\right]\left(\mathrm{L}=\mathrm{G}_{3}\right.$ or $\left.\mathrm{G}_{4}\right)$ at slower rates: $k=(2.6 \pm 0.4) \cdot 10^{7} \mathrm{M}^{-1} \mathrm{~s}^{-1}$ and $(1.6 \pm 0.2) \cdot 10^{7} \mathrm{M}^{-1} \mathrm{~s}^{-1}$ for $n=3[50] ; k=$ $2 \cdot 10^{7} \mathrm{M}^{-1} \mathrm{~s}^{-1}$ and $9 \cdot 10^{6} \mathrm{M}^{-1} \mathrm{~s}^{-1}$ for $n=4$ [51]. All these species decay with a first-order rate law, independent of copper concentration but dependent on $\mathrm{pH}$. The formation of 2-methylpropene for the $\mathrm{CH}_{2} \mathrm{CMe}_{2} \mathrm{OH}$ system, according to eq. (4), was confirmed in a later investigation [52].

The pulse radiolysis study of $\mathrm{L} / \mathrm{Cu}{ }^{\mathrm{II}}(\mathrm{L}=$ glycine or $\alpha$-alanine) solutions in the absence of organic additives showed that the primary ${ }^{\circ} \mathrm{OH}$ radicals scavenge an $\mathrm{H}$ atom from the free or coordinated aminoacid, mainly at the $\alpha-\mathrm{C}$ atom, to yield $\mathrm{RC}^{\cdot}\left(\mathrm{NH}_{3}{ }^{+}\right) \mathrm{CO}_{2}{ }^{-}$, which is then oxidized to iminium ion by $\mathrm{L} / \mathrm{Cu}^{\mathrm{II}}$. In this case, a transient containing a $\mathrm{L} / \mathrm{Cu}^{\mathrm{III}}-\mathrm{C}$ bond was not observed, whereas the evidence suggested the formation of $\mathrm{L} / \mathrm{Cu}{ }^{\text {III }}-\mathrm{OH}$ complexes [53].

As stated above, the pulse radiolytic study of ${ }^{\circ} \mathrm{CH}_{3}$ with $\mathrm{Cu}^{2+}$ aq was not possible. However, the addition of a donor ligand speeds up the radical addition and stabilizes the organocopper(III) product. Both effects are probably due to the lowering of the oxidation potential by the ligands. Thus, the addition of ${ }^{\circ} \mathrm{CH}_{3}$, which is readily generated from $\mathrm{N}_{2} \mathrm{O}$-saturated aqueous solutions in the presence of DMSO according to eq. (12), to $\mathrm{Cu}$ (II) glycinate resulted in the formation of $\left[\left(\mathrm{NH}_{2} \mathrm{CH}_{2} \mathrm{CO}_{2}\right) \mathrm{Cu}^{\mathrm{III}}-\mathrm{CH}_{3}\right]$, showing an absorption maximum at ca. $360 \mathrm{~nm}$, with a rate constant $k$ $>10^{7} \mathrm{M}^{-1} \mathrm{~s}^{-1}$ [54] ( $c f$. $(7.4 \pm 0.6) \cdot 10^{5} \mathrm{M}^{-1} \mathrm{~s}^{-1}$ for the addition to $\mathrm{Cu}^{2+}$ aq [47]). This product rearranges by a first-order process with $k=(1.0 \pm 0.3) \cdot 10^{3} \mathrm{~s}^{-1}$ to an isomer with a similar structure, as suggested by the similarity of the absorption spectra, and the latter undergoes first-order decomposition with $k=0.10 \pm 0.02 \mathrm{~s}^{-1}$, yielding methane and ethane. Interestingly, the decomposition of this transient does not produce methanol (as expected from reaction (3)). Methane was proposed to result from protonolysis, eq. (5), whereas ethane was proposed to result from reaction (13) and not from bimolecular radical coupling, on the basis of the kinetics and literature analogies. The reactivity switch for the decomposition process (solvolytic oxidation for $\left[\mathrm{Cu}^{\mathrm{III}}-\mathrm{CH}_{3}\right]^{2+}{ }_{\text {aq }}$, eq. (3); protonolysis 
for $\left[\left(\mathrm{NH}_{2} \mathrm{CH}_{2} \mathrm{CO}_{2}\right) \mathrm{Cu}^{\mathrm{III}}-\mathrm{CH}_{3}\right]$, eq. (5)) stems from the strong electron-donating effect of the glycinate ligand, alleviating the $\mathrm{Cu}^{\mathrm{III}}$ oxidizing power. It is also of interest to note that the related reaction between the same $\mathrm{Cu}^{\mathrm{II}}$ glycinate complex and benzyl radicals, generated by sonolysis of $\mathrm{Cl}-\mathrm{CH}_{2} \mathrm{Ph}$, led to the production of $\mathrm{PhNHCH}_{2} \mathrm{COOH}$ [55]. The different outcome could derive from the considerably stronger oxidizing power of the methyl radical.

$$
\begin{aligned}
& \mathrm{OH}^{\cdot}+\left(\mathrm{CH}_{3}\right)_{2} \mathrm{SO} \rightarrow \mathrm{CH}_{3}^{\cdot}+\mathrm{CH}_{3} \mathrm{SOOH} \\
& {\left[\mathrm{L} / \mathrm{Cu}^{\mathrm{III}}-\mathrm{CH}_{3}\right]+{ }^{\cdot} \mathrm{CH}_{3} \rightarrow\left[\mathrm{L}^{-\mathrm{Cu}^{\mathrm{II}}}\right]+\mathrm{C}_{2} \mathrm{H}_{6}}
\end{aligned}
$$

The same $\left[\mathrm{Cu}^{\mathrm{II}}\left(\mathrm{G}_{3}\right)\right]$ system investigated in the reaction with substituted radicals (see above) was also later reinvestigated in the reaction with ${ }^{\circ} \mathrm{CH}_{3}$, generated by pulse radiolysis in the presence of DMSO [52]. The $\left[\left(\mathrm{G}_{3}\right) \mathrm{Cu}^{\mathrm{III}}-\mathrm{CH}_{3}\right]$ complex, which forms with $k=1.3 \cdot 10^{8} \mathrm{M}^{-1} \mathrm{~s}^{-1}$, is rather stable, first rearranging by a first-order process $\left(k=120 \mathrm{~s}^{-1}\right)$ to an isomer with a similar structure and then undergoing a first-order decomposition $\left(k=0.0035 \mathrm{~s}^{-1}\right)$ to yield mostly methanol (eq. (3)). However, small amounts of methane and ethane indicate the presence of competing reactions. Evidence was presented in favor of the formation of ethane mostly by reaction (13) $\left(L /=G_{3}\right)$, for which the rate constant was estimated as $5 \cdot 10^{9} \mathrm{M}^{-1} \mathrm{~s}^{-1}$.

Following the above work, where sufficiently stable organocopper(III) transients were generated and characterized from the spectroscopic and kinetic points of view, other reports have followed where species of this kind were invoked as intermediate in copper-catalyzed radical reactions [6, 11, 56-59] and stable organocopper(III) complexes were isolated and fully characterized (next section).

\section{B.4. Isolated organocopper(III) complexes}

$\mathrm{Cu}^{\mathrm{III}}$ has a d ${ }^{8}$ electronic configuration. As such, it prefers to adopt a square planar coordination geometry surrounded by strong field ligands, like the heavier congener $\mathrm{Au}^{\mathrm{III}}$ and the more common Group $10 \mathrm{Ni}^{\mathrm{II}}, \mathrm{Pd}^{\mathrm{II}}$ and $\mathrm{Pt}^{\mathrm{II}}$ and group $9 \mathrm{Rh}^{\mathrm{I}}$ and $\mathrm{Ir}^{\mathrm{I}}$ metal ions. With only one exception, stable organocopper(III) systems were found to adopt this geometry.

Alkyls are amongst the strongest field ligands, especially when fluorinated. The earliest fully characterized organocopper(III) derivatives are the dithiocarbamato derivative $\left[\mathrm{Cu}^{\mathrm{III}}\left(\mathrm{CF}_{3}\right)_{2}\right.$ $\left.\left(\mathrm{S}_{2} \mathrm{CNEt}_{2}\right)\right], 1$ [60], and the homoleptic tetraalkyl anions $\left[\mathrm{Cu}^{\mathrm{III}}\left(\mathrm{R}_{\mathrm{F}}\right)_{4}\right]^{-}\left(\mathrm{R}_{\mathrm{F}}=\mathrm{CF}_{3}[61], \mathrm{CF}_{2} \mathrm{H}\right.$ [62]), $\mathbf{2}$, isolated as the bis(triphenylphosphine)iminium (PNP) salt. These are remarkably stable compounds, being formed by oxidation of organocuprate(I) derivatives, even by air, or by disproportionation of the same anions with formation of $\mathrm{Cu}^{0}$. Transmetallation of $\left[\mathrm{Cu}^{\mathrm{III}} \mathrm{Br}_{2}\right.$ $\left.\left(\mathrm{S}_{2} \mathrm{CNEt}_{2}\right)\right]$ with $\mathrm{Cd}\left(\mathrm{CF}_{2} \mathrm{H}\right)_{2}$ gave $\left[\mathrm{Cu}^{\mathrm{III}}\left(\mathrm{CHF}_{2}\right)_{4}\right]^{-}$selectively, while transmetallation of $\left[\mathrm{Cu}^{\mathrm{III}}\left(\mathrm{CF}_{3}\right)_{2}\left(\mathrm{~S}_{2} \mathrm{CNEt}_{2}\right)\right]$ yielded a mixture of the mixed $\left[\mathrm{Cu}^{\mathrm{III}}\left(\mathrm{CF}_{3}\right)_{\mathrm{n}}\left(\mathrm{CF}_{2} \mathrm{H}\right)_{4-\mathrm{n}}\right]^{-}$species $(\mathrm{n}=0-4)$ [62]. It can be easily appreciated that these organocopper(III) derivatives are less susceptible to the decomposition pathways outlined in sections B.2 and B.3 (eq. (3)-(5)) because of the low polarity of the $\mathrm{Cu}^{\mathrm{III}}-\mathrm{R}_{\mathrm{F}}$ bonds and lack of $\beta-\mathrm{H}$ atoms. In addition, the high bond strength, which is linked to 
the high reactivity of the fluorinated alkyl radicals, renders the homolytic cleavage (reverse of eq. (1)) and the alkyl-alkyl reductive elimination unfavorable.
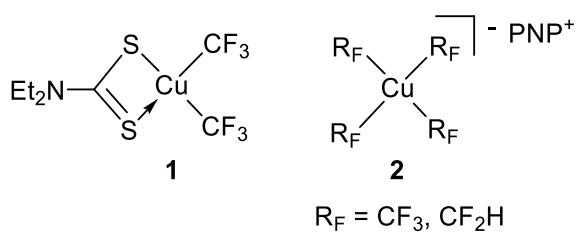

Figure 1. Structurally characterized copper(III) complexes containing fluorinated alkyl groups.

A series of elusive $\left[\mathrm{Cu}^{\mathrm{III}} \mathrm{R}_{4}\right]^{-}[63],\left[\mathrm{Cu}^{\mathrm{III}} \mathrm{R}_{3}(\mathrm{X})\right]^{-}\left(\mathrm{X}=\right.$ halide, $\mathrm{CN}, \mathrm{SCN}, \mathrm{SPh}, \mathrm{PPh}_{2}$, etc.) [63-66], [LCu ${ }^{\text {III }} \mathrm{R}_{3}$ ] (4) [67] and [( $\eta^{3}-$ allyl) $\mathrm{Cu}^{\mathrm{III}} \mathrm{R}_{2}$ ] (5) [68] complexes with non-fluorinated alkyl groups were generated in the Bertz group from Gilman's reagent $\left(\mathrm{Me}_{2} \mathrm{CuLi}\right)$ or from the cyano Gilman reagent $\left(\mathrm{Me}_{2} \mathrm{CuLi} \cdot \mathrm{LiCN}\right)$ by rapid injection techniques at low temperature $\left(-100^{\circ} \mathrm{C}\right)$ and characterized by nuclear magnetic resonance (NMR) spectroscopy. One example is detailed in Figure $2[64,69]$. The stability of these systems depends on the nature of the ancillary ligands, but decomposition generally occurs upon warming above $-80^{\circ} \mathrm{C}$ to generate products of alkyl-alkyl reductive elimination. Complex $\left[\mathrm{Cu}^{\mathrm{III}} \mathrm{Me}_{4}\right]^{-}$, prepared in high yields from $\left[\mathrm{Me}_{2} \mathrm{CuLi} \cdot \mathrm{LiX}\right]$ and MeLi in a $1: 2$ ratio at $-100^{\circ} \mathrm{C}$, was surprisingly stable $\left(\mathrm{t}_{1 / 2}=7 \mathrm{~h}\right.$ at $0^{\circ} \mathrm{C}, 0.75 \mathrm{~h}$ at $\left.20^{\circ} \mathrm{C}\right)$ [70]. Note that these stabilized organocopper(III) species containing two or more alkyl groups spontaneously degrade by alkyl-alkyl reductive elimination, eq. (14), and that this chemistry does not involve radicals (see also section B.5).

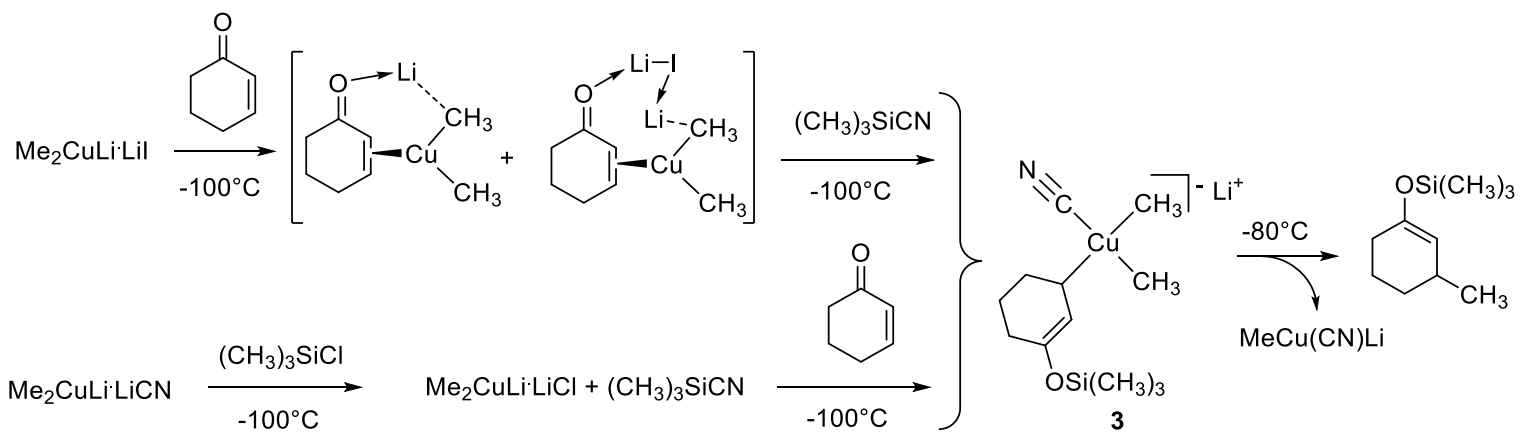

Figure 2. Low-temperature preparation of an elusive trialkylcyanocuprate(III) derivative.

$$
\left[\mathrm{L} / \mathrm{Cu}^{\mathrm{III}}(\mathrm{R})_{2}\right] \rightarrow\left[\mathrm{L} / \mathrm{Cu}^{\mathrm{I}}\right]+\mathrm{R}-\mathrm{R}
$$

reductive elimination

A class of stable organocopper(III) complexes contain the so-called "confused porphyrins", structurally analogous to porphyrins but with the macrocylic ligand modified by replacement of one or more pyrrole rings to yield a corresponding number of inward-pointing $\mathrm{C}$ atoms for metal binding. In compounds 4 [71] and 5 [72], the ligands are doubly $\mathrm{N}$-confused porphyrins, since they contain two pyrrole rings (respectively in a relative cis and trans arrangement) incorporated in the macrocycle via the 2 and $4 \mathrm{C}$ atoms rather than the 2 and $5 \mathrm{C}$ atoms, thus binding the $\mathrm{Cu}^{\mathrm{III}}$ center 
via the pyrrole $3 \mathrm{C}$ atom. These compounds can be reversibly protonated and deprotonated and also electrochemically reduced [73]. Compound 6 contains a singly N-confused porphyrin. It was obtained by one-electron oxidation, coupled with deprotonation, of a corresponding organocopper(II) complexes that will be described later in section C.4 [74]. Compound 7 containing a pyrrole-appended oxacarbaporphyrin ligand (an O-confused porphyrin), on the other hand, formed spontaneously upon coordination of the free ligand to copper(II) acetate [75]. Interestingly, further aerial oxidation results in aromatization of the furane ring and metal reduction, yielding an organocopper(II) complex (see section C.4).

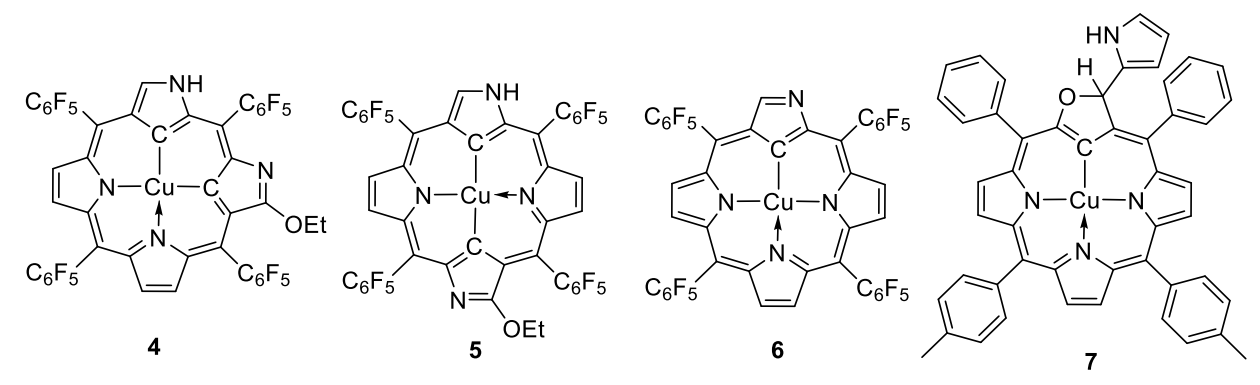

Figure 3. A few isolated organocopper(III) compounds with the $\mathrm{Cu}$-bonded $\mathrm{C}$ atom incorporated in confused porphyrin rings.

Additional stable organocopper(III) derivatives were obtained when supported by rigid planar nonporphyrin-type tetradentate ligands that also provided a C-bonding site by the $\mathrm{C}-\mathrm{H}$ activation of an aromatic group. One family of compounds includes the dicationic square planar compounds 8 [76, 77] and the monocationic 5-coordinate complexes 9 [77, 78]. They were obtained by interaction in $\mathrm{MeCN}$ of the free ligand with $\mathrm{Cu}^{\mathrm{II}}$ salts, see Figure 4 . The initially formed paramagnetic $\mathrm{Cu}^{\mathrm{II}}$ ligand adduct $\left[\mathrm{Cu}{ }^{\mathrm{II}} \mathrm{L}\right](\mathrm{X})_{2}$ rapidly decayed under anaerobic conditions to form a 1:1 mixture of the diamagnetic $\mathrm{Cu}^{\mathrm{I}}$ and organocopper(III) salts, either $\left[\mathrm{Cu}^{\mathrm{III}} \mathrm{L}^{\prime}\right](\mathrm{X})_{2}$ or $\left[\mathrm{Cu}^{\mathrm{III}} \mathrm{L}^{\prime} \mathrm{X}\right] \mathrm{X}$ depending on the nature of $\mathrm{X}$, where the ligand $\mathrm{L}^{\prime}$ is the $\mathrm{C}-\mathrm{H}$ activated version of $\mathrm{L}$. Complexes $\mathbf{8}$ are indefinitely stable in protic media $\left(\mathrm{H}_{2} \mathrm{O}, \mathrm{MeOH}\right)$ and in air. The coordination geometry, determined by X-ray diffraction for $\left[\mathrm{CuL}^{2}\right]\left(\mathrm{ClO}_{4}\right)_{2}$ where $\mathrm{n}=1, \mathrm{R}_{1}=\mathrm{Me}$ and $\mathrm{R}_{2}=\mathrm{H}$, is distorted square planar, with the two anions loosely interacting with the metal center above and below the coordination plane. Complexes 9 undergo an $\mathrm{H}^{+}$-triggered $\mathrm{C}$-X reductive elimination. The reverse reaction, aryl- $\mathrm{X}$ oxidative addition to $\mathrm{Cu}^{\mathrm{I}}$ to regenerate aryl-Cu $\mathrm{Cu}^{\mathrm{III}}-\mathrm{X}$, proceeds rapidly in the absence of an acid source and is reminiscent of one of the fundamental steps of the copper-catalyzed UllmannGoldberg cross-coupling reactions.
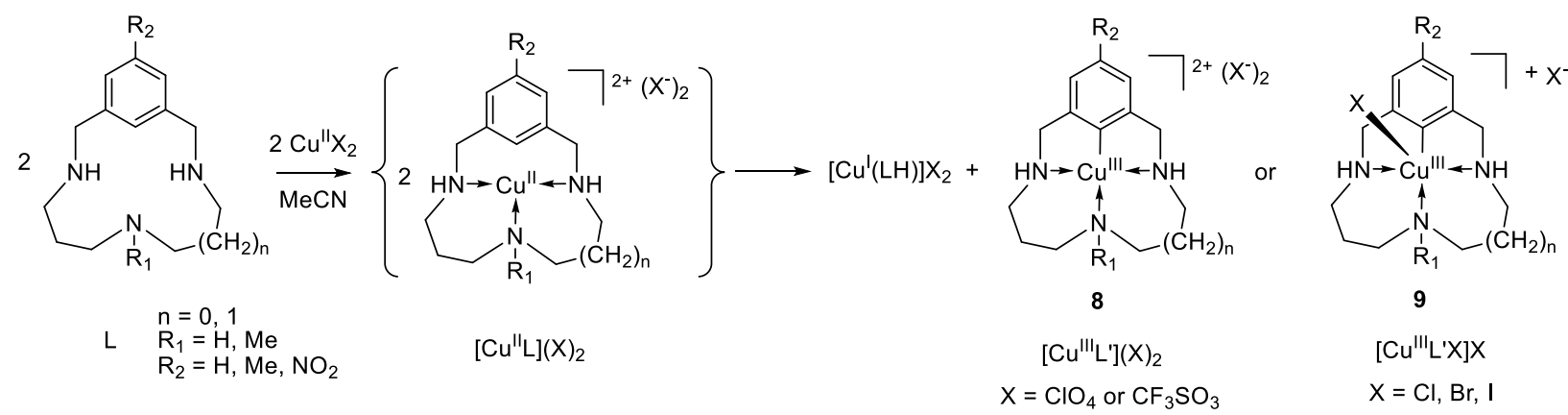
Figure 4. Generation of organocopper(III) compounds by C-H activation of a triazamacrocycle.

A similar compound, 10, also containing a $\kappa^{4}-\mathrm{CN}_{3}$ macrocycle, was obtained by a similar process, see Figure 5 [79]. The X-ray structure of the product shows a saddle-shaped calixarene ligand, though the coordination geometry of the $\mathrm{Cu}^{\mathrm{III}}$ center is square planar.

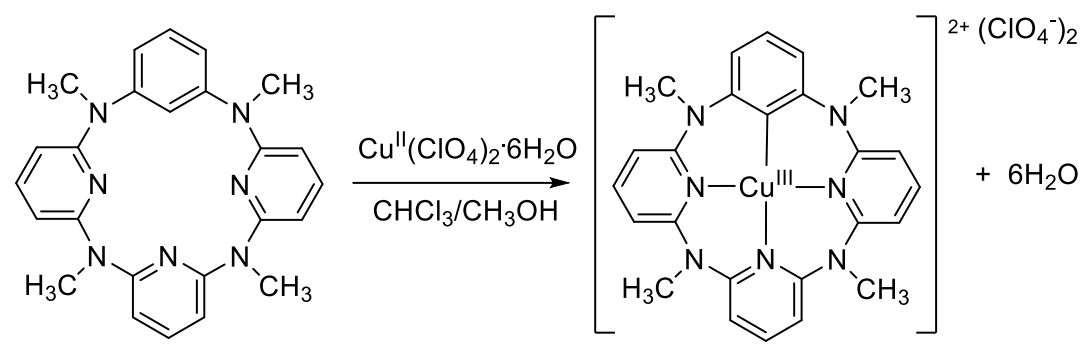

10

Figure 5. Generation of organocopper(III) compounds by $\mathrm{C}-\mathrm{H}$ activation of a tetraazacalix[1]arene[3]pyridine.

While the $\mathrm{d}^{8}$ configuration of $\mathrm{Cu}^{\mathrm{III}}$ leads to a natural preference for a square-planar geometry, oneelectron oxidation of the trigonal bipyramidal $\left[(\mathrm{TPDM}) \mathrm{Cu}{ }^{\mathrm{II}} \mathrm{Cl}\right]$ complex $(\mathrm{TPDM}=\operatorname{tris}(2-$ pyridylthio)methane), which will be described below in section C.4, affords the [(TPDM)Cu $\left.{ }^{\mathrm{III}} \mathrm{Cl}\right]^{+}$ ion (11) which maintains the same structure (Figure 6), unusual for $\mathrm{Cu}^{\mathrm{III}}$, as confirmed by an $\mathrm{X}$ ray diffraction study for the $\mathrm{PF}_{6}^{-}$salt [80].

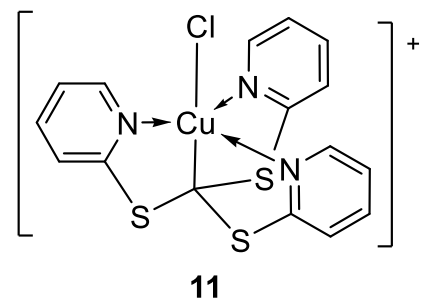

Figure 6. A thermally stable organocopper(III) complex with an unusual trigonal bipyramidal geometry.

\section{B.5. Reaction with organocopper(II) complexes}

A reaction pathway of interest is the putative interaction between carbon-centered radicals and $\mathrm{Cu}^{\mathrm{II}}$ complexes that already contain an alkyl group in the coordination sphere (reaction (15)). The straight radical addition to the metal center would lead to dialkylcopper(III) species, which would readily evolve by reductive elimination as demonstrated for many such transients, see previous section and eq. (14). This would represent a possible pathway for the recently discovered "catalyzed radical termination" (CRT) [81].

$$
\left[\mathrm{L} / \mathrm{Cu}^{\mathrm{II}}-\mathrm{R}\right]+\mathrm{R}^{\bullet} \rightarrow\left[\mathrm{L} / \mathrm{Cu}^{\mathrm{III}}(\mathrm{R})_{2}\right] \text { or decomposition products }
$$


Certain ATRP-active copper(I) complexes (Scheme 1) were also found able to trigger a catalytic radical termination process, specifically for polyacrylate chains, when the ligand system is engineered to yield a high activation equilibrium constant $\left(K_{\mathrm{ATRP}}=k_{\mathrm{a}} / k_{\mathrm{da}}\right)$. This is an unwanted phenomenon because it reduces the chain-end fidelity of the recovered $\mathrm{P}_{\mathrm{n}}-\mathrm{X}$ macromolecules $(\mathrm{X}=$ $\mathrm{Cl}$ or $\mathrm{Br}$ ). Subsequent work in our [82-85] and other [86] groups has pointed toward the likely involvement of organocopper(II) transients, which would be obtained in the polymerization system by radical addition to the $\mathrm{Cu}^{\mathrm{I}}$ ATRP catalyst (OMRP equilibrium, Scheme 2).

There appear to be no precedents for reaction (15), which can be attributed to the paucity of welldefined organocopper(II) complexes (see section C.4). If CRT proceeds via reaction (15) followed by reductive elimination, only coupled chains $\left(\mathrm{P}_{\mathrm{n}}-\mathrm{P}_{\mathrm{m}}\right)$ should be produced. We [85] and the Yamago group [86] have independently made efforts to determine the nature of the terminated polymer chains. Yamago et al. run termination experiments from well-defined poly(methyl acrylate) ATRP macroinitiators (PMA-Br) with the highly active $[\mathrm{L} / \mathrm{Cu}]^{+}$catalyst where $\mathrm{L}=$ $\mathrm{Me}_{6}$ TREN (Figure 7), obtaining a bimodal distribution of terminated chains. The lighter distribution has the same average molecular weight (MW) as the PMA-Br macroinitiator and saturated chain ends (PMA-H), while the heavier distribution has a double average MW, corresponding to coupled chains (PMA-PMA) [86]. These authors attributed the PMA-H product to hydrolysis of the $\left[\mathrm{L} / \mathrm{Cu}^{\mathrm{II}}-\mathrm{PMA}\right]^{+}$intermediate by adventitious water (undried toluene was used as solvent in this study) and the PMA-PMA coupling product to CRT via the sequence of reactions (15) and (14). However, in our analogous termination experiments run in carefully dried MeCN solutions with a wider range of $\left[\mathrm{L} / \mathrm{Cu}^{\mathrm{I}}\right]^{+}$catalysts ( $\mathrm{L}=\mathrm{TPMA}$, TPMA*3 ${ }^{*}, \mathrm{Me}_{6} \mathrm{TREN}$; Figure 7$)$, and in the presence of variable amounts of the corresponding $\left[\mathrm{L} / \mathrm{Cu}^{\mathrm{II}} \mathrm{Br}\right]^{+}$deactivator to tune the ratio between spontaneous bimolecular termination and CRT, we have unambiguously shown that the coupled chains result from the former process, because free radicals are initially produced in large amounts, while the CRT process leads to products with an average molecular weight identical to that of the macroinitiator [85]. Further work, outlined later in section C.3, has revealed the key role of the $\mathrm{MeCN}$ solvent in this process.

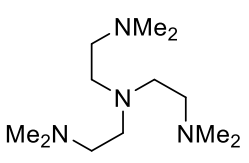

$\mathrm{Me}_{6}$ TREN

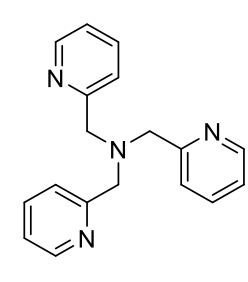

TPMA

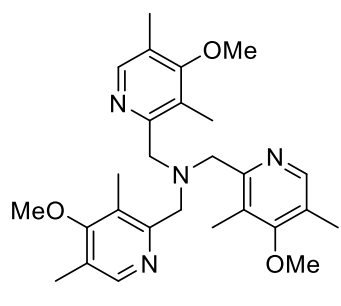

TPMA $^{* 3}$

Figure 7. Ligands used for the investigation of $\mathrm{Cu}$-catalyzed radical termination.

In conclusion, there is so far no concrete evidence for the occurrence of reaction (15). This is in contrast to the above-discussed evidence in favor of the reaction between free carbon-center radicals and alkyl groups bonded to $\mathrm{Cu}^{\mathrm{III}}$, e.g. eq. (13). 


\section{Interaction with copper(I) complexes}

\section{C.1. General considerations}

The primary processes of interest in this section are the formation of a $\mathrm{Cu}^{\mathrm{II}}-\mathrm{R}$ bond by direct addition of a carbon-centered radical to $\left[\mathrm{L} / \mathrm{Cu}^{\mathrm{I}}\right]$, eq. (16), and the modes of decomposition or further reactivity of the organocopper(II) species. As discussed at the end of the last section (B.5), this phenomenon is relevant for a possible controlled polymerization by OMRP (Scheme 2) and for the mechanism of CRT.

$$
\left[\mathrm{L} / \mathrm{Cu}^{\mathrm{I}}\right]+\mathrm{R}^{\cdot} \rightarrow\left[\mathrm{L} / \mathrm{Cu}^{\mathrm{II}}-\mathrm{R}\right]
$$

Depending on the nature of $\mathrm{L}$ and $\mathrm{R}$ and on the presence of additional external reagents, these organocopper(II) species were shown to evolve in various ways, the main ones being those shown in eqs. (17)-(21), as will be detailed below. In the case of eq. (21), the final product depends on the nature of $\mathrm{R}$ and on the presence of other species, e.g. free $\left[\mathrm{L} / \mathrm{Cu}^{\mathrm{II}}\right]$.

$$
\begin{aligned}
& {\left[\mathrm{L} / \mathrm{Cu}^{\mathrm{II}}-\mathrm{R}\right]+\mathrm{H}^{+} \rightarrow\left[\mathrm{L} / \mathrm{Cu}^{\mathrm{II}}\right]+\mathrm{RH}} \\
& {\left[\mathrm{L} / \mathrm{Cu}^{\mathrm{II}}-\mathrm{C}-\mathrm{C}-\mathrm{X}\right]+\mathrm{H}^{+} \rightarrow\left[\mathrm{L} / \mathrm{Cu}^{\mathrm{II}}\right]+\mathrm{C}=\mathrm{C}+\mathrm{HX}} \\
& 2\left[\mathrm{~L} / \mathrm{Cu}^{\mathrm{II}}-\mathrm{R}\right] \rightarrow 2\left[\mathrm{~L} / \mathrm{Cu}^{\mathrm{I}}\right]+\mathrm{R}-\mathrm{R} \\
& {\left[\mathrm{L} / \mathrm{Cu}^{\mathrm{II}}-\mathrm{R}\right]+\left[\mathrm{L} / \mathrm{Cu}^{\mathrm{II}}\right]+\mathrm{H}_{2} \mathrm{O} \rightarrow 2\left[\mathrm{~L} / \mathrm{Cu}^{\mathrm{II}}\right]+\mathrm{RH}+\mathrm{OH}^{-}} \\
& {\left[\mathrm{L} / \mathrm{Cu}^{\mathrm{II}}-\mathrm{R}\right] \rightleftarrows\left[\mathrm{L} / \mathrm{Cu}^{\mathrm{I}}\right]+\mathrm{R}^{\circ}}
\end{aligned}
$$

protonolysis

protonolytic $\beta$ elimination

bimolecular reductive elimination

bimolecular protonolysis

homolysis

In early work published by the Kochi group, [L/Cu $\left.{ }^{\mathrm{II}}-\mathrm{R}\right]$ species were invoked as intermediates in the very rapid reductions of copper(II) acetate, triflate, and chloride by tetraethyllead [40, 87, 88], but these reactive intermediates were not directly observed. Evidence for the formation of observable organocopper(II) transients from the interaction of carbon-centered radicals and $\mathrm{L} / \mathrm{Cu}^{\mathrm{I}}$ was first mentioned in the Freibert-Meyerstein pulse radiolysis contribution already detailed in the previous section [38]. While the study was devoted to the interaction between the ${ }^{\circ} \mathrm{CH}_{2} \mathrm{CO}_{2}{ }^{-}$radical and $\mathrm{Cu}^{2+}{ }_{\text {aq }}$, the kinetics suggested that the radical is also able to react with the $\mathrm{Cu}^{+}{ }_{\text {aq }}$ ion formed under the experimental conditions, yielding a short-lived $\left[\mathrm{Cu}^{\mathrm{II}} \mathrm{CH}_{2} \mathrm{CO}_{2}\right]_{\text {aq }}$ intermediate.

\section{C.2. Reactions with $\mathrm{Cu}^{+}{ }^{+}$}

The investigation of the interaction between carbon-centered radicals and $\mathrm{Cu}^{\mathrm{I}}$ in aqueous solutions is complicated by the instability of $\mathrm{Cu}^{+}{ }_{a q}$, leading to disproportionation $\left(\mathrm{Cu}^{2+}{ }_{\text {aq }}\right.$ and $\left.\mathrm{Cu}^{0}\right)$. However, metastable solutions of $\mathrm{Cu}^{+}$aq are accessible in the presence of $\mathrm{Cu}^{2+}{ }_{\text {aq }}$, provided no $\mathrm{Cu}^{0}$ is present. Later, it was found that relatively concentrated solutions of $\mathrm{Cu}^{+}{ }_{\text {aq }}$ (up to $2 \cdot 10^{-4} \mathrm{M}$ ), free of $\mathrm{Cu}^{2+}{ }_{\text {aq }}$ and stable for a few hours at $\mathrm{pH} \leq 4.0$, can be prepared by adding $\left[\mathrm{Cu}\left(\mathrm{NH}_{3}\right)_{6}\right]^{+}$to acidic solutions [89]. However, initial studies of the $\mathrm{Cu}^{+}{ }^{+} / \mathrm{R}^{\circ}$ interactions were carried out in the presence of relatively high concentration of $\mathrm{Cu}^{2+}{ }_{\text {aq }}$. Thus, because of the interference of the $\left[\mathrm{Cu}^{\mathrm{III}}-\mathrm{R}\right]^{2+}{ }_{\text {aq }}$ 
formation and the similarity of the $\left[\mathrm{Cu}^{\mathrm{II}}-\mathrm{R}\right]^{+}{ }_{\text {aq }}$ and $\left[\mathrm{Cu}^{\mathrm{III}}-\mathrm{R}\right]^{2+}{ }_{\text {aq }}$ spectroscopic properties, clean studies were restricted to those radicals for which the intermediates of type $\left[\mathrm{Cu}^{\mathrm{III}}-\mathrm{R}\right]^{2+}$ are unobservable because too short-lived, or which form on a much lower timescale, which is fortunately true in most cases $\left(\right.$ e.g. $\sim 5 \cdot 10^{9} \mathrm{M}^{-1} \mathrm{~s}^{-1}$ for $\mathrm{Cu}^{+}{ }_{\text {aq }} v$ s. $\sim 5 \cdot 10^{7} \mathrm{M}^{-1} \mathrm{~s}^{-1}$ for $\mathrm{Cu}^{2+}{ }_{\text {aq }}$ for the ${ }^{\cdot} \mathrm{CMe}_{2} \mathrm{OH}$ radical $\left.[42,43]\right)$. The rates of formation were found first order in $\left[\mathrm{Cu}^{+}\right]$and first order in $\left[\mathrm{R}^{\circ}\right]$ and the rate constant increases in the order tertiary < secondary < primary. Pulse radiolysis was used in most of these studies to generate the carbon-centered radicals.

While an investigation reported by Buxton suggested that the $\mathrm{Cu}^{+}{ }_{\mathrm{aq}}-\mathrm{EtOH}$ and $\mathrm{Cu}^{+}{ }_{\mathrm{aq}}-i \mathrm{PrOH}$ systems yield $\left[\mathrm{Cu}^{\mathrm{II}} \mathrm{CHMeOH}\right]^{+}$aq and $\left[\mathrm{Cu}^{\mathrm{II}} \mathrm{CMe}{ }_{2} \mathrm{OH}\right]^{+}{ }_{\text {aq }}$, respectively, as primary products [42], a reinvestigation by the Meyerstein group led to the reformulations of these products as $\left[\mathrm{Cu}^{\mathrm{II}} \mathrm{CH}_{2} \mathrm{CH}_{2} \mathrm{OH}\right]^{+}$aq and $\left[\mathrm{Cu}^{\mathrm{II}} \mathrm{CH}_{2} \mathrm{CHMeOH}\right]^{+}{ }_{\text {aq }}$ [90]. This is in spite of the fact that the reaction of $\mathrm{HO}^{\circ}$ with $\mathrm{EtOH}$ and $i \mathrm{PrOH}$ yields predominantly the more substituted radical, with only 13\% of the less substituted radical. The proposed reason for this preference is that the $\mathrm{Cu}^{\mathrm{II}}-\mathrm{C}$ bonds with the less substituted minority radicals are considerably stronger and thus prevail in the organocopper(II) transient formation. The equilibrium constant for the $\left[\mathrm{Cu}^{\mathrm{II}}-\mathrm{CH}_{2} \mathrm{OH}\right]^{+}$aq bond formation (inverse of eq. (21)) was estimated as $\sim 5 \cdot 10^{3}[42,90]$, while those associated to the formation of $\left[\mathrm{Cu}{ }^{\mathrm{II}}-\mathrm{CHMeOH}\right]^{+}{ }_{\text {aq }}$ and $\left[\mathrm{Cu}^{\mathrm{II}}-\mathrm{CMe} \mathrm{CH}_{2}\right]_{\text {aq }}^{+}$are considerably smaller $\left(<5 \cdot 10^{2}\right)$ [90]. The decomposition of these intermediates is acid-catalyzed and proceeds according to equations (17) (for the $\mathrm{Cu}^{+}{ }_{\mathrm{aq}}-\mathrm{MeOH}$ system) and (18) (for the $\mathrm{Cu}^{+}{ }_{\mathrm{aq}}-\mathrm{EtOH}$ and $i \mathrm{PrOH}$ systems). Other transients containing $\beta-\mathrm{OH}$ groups were also found to decompose according to eq. (18), for instance [ $\mathrm{Cu}^{\mathrm{II}}$ $\left.\mathrm{CH}_{2} \mathrm{CMe}_{2} \mathrm{OH}\right]^{+}{ }_{\text {aq }}$ generated from $\mathrm{Cu}^{+}{ }_{\text {aq }}^{-} t \mathrm{BuOH}$ [91]. The rates of decomposition according to eq. (18) are greater relative to those of corresponding $\mathrm{Fe}^{\mathrm{III}}$ metal complexes, which was attributed to the greater tendency of the $\mathrm{Cu}^{\mathrm{II}}$-C bond to break homolytically [92]. Derivatives with $\beta$-OR groups, such as that obtained from $\mathrm{Cu}^{+}$-dioxane, however, decompose slowly by homolytic cleavage (eq. (21)) and the resulting radical reduces the excess $\mathrm{Cu}^{2+}{ }_{\text {aq }}$ that is present in the pulse radiolysis solution, equation (22). The nature of the oxidation products for eq. (22) was not specified and no evidence was provided for the generation of an intermediate $\left[\mathrm{R}-\mathrm{Cu}^{\mathrm{III}}\right]^{2+}$ aq species [93].

$$
\mathrm{R}^{\cdot}+\mathrm{Cu}^{2+}{ }_{\mathrm{aq}} \rightarrow \mathrm{Cu}^{+}+\text {oxidation products }
$$

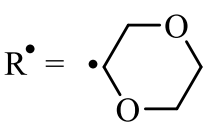

In the course of the investigation of the $\mathrm{CH}_{3}{ }^{-}-\mathrm{Cu}^{2+}{ }_{\text {aq }}$ interaction by Ferraudi already described in the previous section [47], the methyl radicals were found to be trapped in a secondary reaction by the produced $\mathrm{Cu}^{+}$aq ions. Thus, the independent interaction between $\mathrm{CH}_{3}{ }^{\circ}$ (generated by photolytic decomposition of a $\mathrm{Co}^{\mathrm{III}}$ acetate complex, eq. (9)) and $\mathrm{Cu}^{+}$aq was also investigated and reported in the same contribution. The reaction produces a transient $\left[\mathrm{Cu}^{\mathrm{II}} \mathrm{CH}_{3}\right]_{\text {aq }}$ species with an absorption maximum at $370 \mathrm{~nm}$ and a half life of $\sim 50 \mu \mathrm{s}$. The rate of formation by eq. (16) was estimated as $\geq 10^{9} \mathrm{M}^{-1} \mathrm{~s}^{-1}$, i.e. much faster than the addition to $\mathrm{Cu}^{2+}{ }_{\text {aq }}$. The same transient was also generated by photodecomposition of $\left[\mathrm{Cu}^{\mathrm{II}}\left(\mathrm{OCOCH}_{3}\right)\right]_{\text {aq }}$ (eq. (23)) and found to decay according to a secondorder rate law, first order in both transient and $\mathrm{H}^{+}$with $k=(6.2 \pm 0.5) \cdot 10^{7} \mathrm{M}^{-1} \mathrm{~s}^{-1}$, leading to $\mathrm{CH}_{4}$. 
The large yield of $\mathrm{CH}_{4}$ compared with $\mathrm{C}_{2} \mathrm{H}_{6}$ indicates that a significant fraction of the $\mathrm{CH}_{3}{ }^{\circ}$ radicals remains trapped in the organocopper transient.

$$
\left[\mathrm{Cu}^{\mathrm{II}}\left(\mathrm{OCOCH}_{3}\right)\right]_{\mathrm{aq}} \stackrel{\mathrm{h} v}{\longrightarrow}\left[\mathrm{CH}_{3}-\mathrm{Cu}^{\mathrm{II}}\right]_{\mathrm{aq}}+\mathrm{CO}_{2}
$$

Cohen and Meyerstein have subsequently remeasured the rate of the reaction of $\mathrm{CH}_{3}{ }^{\circ}$ radicals with $\mathrm{Cu}^{+}$aq and the spectroscopic properties of the $\left[\mathrm{CH}_{3}-\mathrm{Cu}^{\mathrm{II}}\right]_{\mathrm{aq}}$ transient product [41] with greater precision. The $\mathrm{CH}_{3}{ }^{\circ}$ radicals were generated by pulse radiolysis in the presence of DMSO (eq. (12)), while the $\mathrm{Cu}^{+}$aq ion was generated and maintained in aqueous solutions for long periods (hours) by in situ reduction of $\mathrm{Cu}^{2+}{ }_{\text {aq }}$ with $\mathrm{Cr}^{2+}{ }_{\text {aq }}$, eq. (24). The $\left[\mathrm{CH}_{3}-\mathrm{Cu}^{\mathrm{II}}\right]_{\text {aq }}$ species forms with a rate constant $k=(3.5 \pm 0.4) \cdot 10^{9} \mathrm{M}^{-1} \mathrm{~s}^{-1}$ and shows a spectrum with an absorption maximum at 375 $\mathrm{nm}$. While these results agree with those of Ferraudi, the decomposition was found by CohenMeyerstein, like Ferraudi, to obey a first-order rate law and to yield methane only at $\mathrm{pH} \leq 1.5$, whereas the rate law becomes second order at $\mathrm{pH} \geq 2.5$ and ethane becomes the predominant product. Thus, while the $\left[\mathrm{CH}_{3}-\mathrm{Cu}^{\mathrm{II}}\right]_{\mathrm{aq}}$ species decomposes by protonolysis (eq. (17) to yield methane and $\mathrm{Cu}^{2+}{ }_{\text {aq }}$ at low $\mathrm{pH}$, the preferred pathway at higher $\mathrm{pH}$ involves a bimolecular interaction between two transients (eq. (19)) to give ethane and $\mathrm{Cu}^{+}{ }_{\text {aq. }}$. Possible alternative pathways involving a homolytic decomposition pre-equilibrium to yield $\mathrm{Cu}^{+}$aq and $\mathrm{CH}_{3}{ }^{\circ}$, followed by bimolecular radical combination, or by the reaction between $\mathrm{CH}_{3}{ }^{\circ}$ and a second transient, were excluded on the basis of the observation that the decomposition rate does not depend on $\left[\mathrm{Cu}^{+}\right]$. This is an important observation in light of our discussion in section B.5 on the possible radical combination process in CRT. The intimate mechanism could involve either direct $\mathrm{C}-\mathrm{C}$ bond formation between two transients, or a rate-limiting methyl transfer to generate $\mathrm{Cu}^{+}$aq and $\left[\mathrm{Cu}^{\mathrm{III}}\left(\mathrm{CH}_{3}\right)_{2}\right]_{\mathrm{aq}}$, the latter of which would proceed by reductive elimination [41]. These results were confirmed in a subsequent reinvestigation with $\mathrm{Cu}^{+}{ }_{\text {aq }}$ solutions free of $\mathrm{Cu}^{2+}{ }_{\text {aq }}$ [89].

$$
\mathrm{Cu}^{2+}{ }_{\mathrm{aq}}+\mathrm{Cr}^{2+}{ }_{\mathrm{aq}} \rightarrow \mathrm{Cu}^{+}{ }_{\mathrm{aq}}+\mathrm{Cr}^{3+}{ }_{\mathrm{aq}}
$$

Related transient species containing a $\mathrm{Cu}^{\mathrm{II}}-\mathrm{C}$ bond, [ $\left.\mathrm{Cu}^{\mathrm{II}}-\mathrm{COO}\right]_{\mathrm{aq}}[94]$ and $\left[\mathrm{Cu}^{\mathrm{II}}-\mathrm{CH}_{2} \mathrm{NH}_{2}\right]^{+}{ }_{\mathrm{aq}}$ [95], were produced by the group of Johnson by either flash photolysis of $\mathrm{Cu}^{\mathrm{II}}$ oxalate (eq. (25)) or glycinate (eq. (26)) or by pulse radiolysis of $\mathrm{Cu}^{2+}$ aq solutions in the presence of formate (eq. (16), $\mathrm{R}^{\cdot}={ }^{\circ} \mathrm{CO}_{2}{ }^{-}$) [94]. These species have absorption maxima below $400 \mathrm{~nm}$, similar to those of the above mentioned species described by Buxter and Meyerstein. On the basis of the observed kinetics, of the dependence on $\mathrm{pH}$ and $\left[\mathrm{Cu}^{2+}\right]$ and of other factors, the decay of the $\left[\mathrm{Cu}^{\mathrm{II}}-\mathrm{COO}\right]_{\mathrm{aq}}$ transient was proposed to occur by two independent pathways, a protonolysis yielding $\mathrm{Cu}^{2+}{ }_{\text {aq }}$ and formic acid, which is dominant at low $\mathrm{pH}$, and an oxidation by $\mathrm{Cu}^{2+}$ aq to yield $\mathrm{Cu}^{+}$aq and $\mathrm{CO}_{2}$, which is dominant ay $\mathrm{pH}>3$. The $\left[\mathrm{Cu}^{\mathrm{II}}-\mathrm{CH}_{2} \mathrm{NH}_{2}\right]^{+}$aq transient is oxidized by $\mathrm{Cu}^{2+}{ }_{\text {aq }}$ to yield formaldehyde and ammonia. 


$$
\left[\mathrm{Cu}^{\mathrm{II}}\left(\mathrm{C}_{2} \mathrm{O}_{4}\right)\right] \stackrel{\mathrm{h} v}{\longrightarrow}\left[\mathrm{Cu}^{\mathrm{II}} \mathrm{COO}\right]_{\mathrm{aq}}+\mathrm{CO}_{2}
$$

$$
\left[\mathrm{Cu}^{\mathrm{II}}\left(\mathrm{NH}_{2} \mathrm{CH}_{2} \mathrm{COO}\right)_{2}\right] \stackrel{\mathrm{h} v}{\longrightarrow}\left[\mathrm{Cu}^{\mathrm{II}} \mathrm{CH}_{2} \mathrm{NH}_{2}\right]^{+}{ }_{\mathrm{aq}}+\mathrm{CO}_{2}+\mathrm{NH}_{2} \mathrm{CH}_{2} \mathrm{CO}_{2}{ }^{-}
$$

The interaction of $\mathrm{Cu}^{+}$aq with the ${ }^{\circ} \mathrm{CH}_{2} \mathrm{CMe}_{2} \mathrm{COOH}$ radical, generated in a pulse radiolysis study from $\mathrm{Me}_{3} \mathrm{CCOOH}$, yields the $\left[\mathrm{Cu}^{\mathrm{II}} \mathrm{CH}_{2} \mathrm{CMe}_{2} \mathrm{COOH}\right]^{+}$aq adduct in an equilibrated process, the constant of which was estimated as $K=1.5 \cdot 10^{4}$ [45]. The decomposition of this adduct involves a reaction with $\mathrm{Cu}^{2+}{ }_{\text {aq }}$, leading to the protonolysis product, eq. (20). This process likely results, at least predominantly, from the direct interaction of the two reagents favoring heterolysis, rather than by homolytic $\mathrm{Cu}^{\mathrm{II}}-\mathrm{C}$ bond cleavage followed by oxidation of the radical by $\mathrm{Cu}^{2+}{ }_{\text {aq }}$, because the latter should lead to decarboxylation (see previous section, eq. (8)). Product analysis also showed, however, the formation of the radical combination product, $\left[\mathrm{CH}_{2} \mathrm{CMe}_{2} \mathrm{COOH}\right]_{2}$, and $\mathrm{HOCH}_{2} \mathrm{CMe}_{2} \mathrm{COOH}$. These were suggested to result from reactions between a free radical and the organocopper(III) intermediate [45].

A study of the interaction of the 2-hydroxycyclohexyl radical, generated by pulse radiolysis from ${ }^{\circ} \mathrm{OH}$ and cyclohexene, with $\mathrm{Cu}^{+}{ }_{\text {aq }}$ shows that the resulting organocopper(II) intermediate yields cyclopentanecarbaldehyde as the predominant product. The proposed mechanism of this transformation, shown in Scheme 4, is supported by the observation of deuterium incorporation at position 2 when the reaction was carried out in $\mathrm{D}_{2} \mathrm{O}$ [96]. On the basis of this study, it was suggested that the previously reported copper-catalyzed oxidation of cyclohexene by persulfate to cyclopentanecarbaldehyde [97] proceeds by formation of this key organocopper(II) transient by interaction with $\mathrm{Cu}^{+}$, even though the steady-state concentration of this ion is rather low, and not as previously proposed via the corresponding organocopper(III) transient.

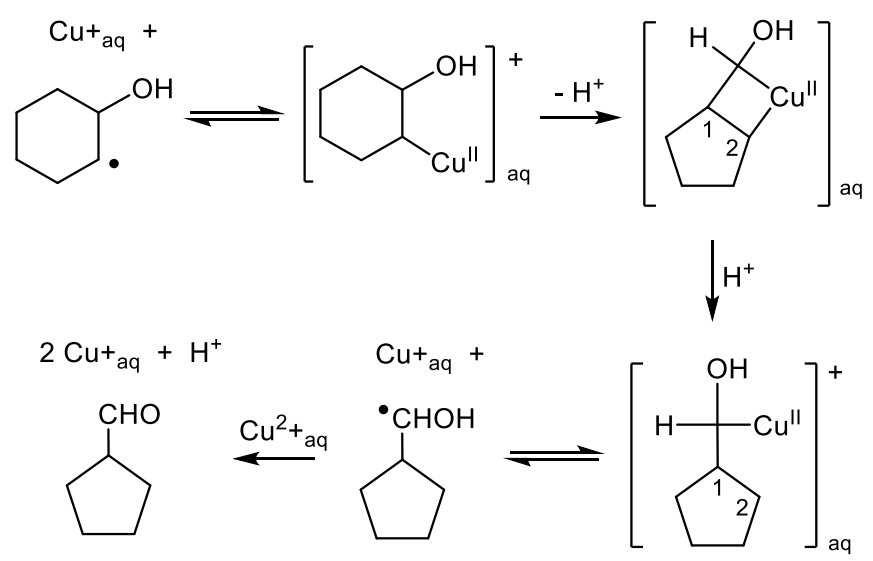

Scheme 4. Proposed mechanism for the rearrangement of 2-hydroxycyclohexylcopper(II) to cyclopentanecarbaldehyde.

The addition of ${ }^{\circ} \mathrm{CH}_{2} \mathrm{CMe}_{2} \mathrm{NH}_{3}{ }^{+}$, generated by pulse radiolysis in the presence of $t \mathrm{BuNH}_{2}$ at $\mathrm{pH}<$ 10.5, yields $\left[\mathrm{Cu}^{\mathrm{II}}-\mathrm{CH}_{2} \mathrm{CMe}_{2} \mathrm{NH}_{3}\right]^{2+}$ aq by reaction (16) with $k=(1.2 \pm 1.0) \cdot 10^{9} \mathrm{M}^{-1} \mathrm{~s}^{-1}$, only a bit 
slower than that with the related ${ }^{\circ} \mathrm{CH}_{2} \mathrm{CMe}_{2} \mathrm{OH}$ radical generated from $t \mathrm{BuOH}$, presumably because of the positive charge, although this addition rate constant is similar to those reported for other aliphatic radicals. This transient was found to decompose to yield isobutene and ammonia (eq. (18)) with a first-order rate law that was independent on $\mathrm{pH}$, since the $\mathrm{X}$ function being eliminated is already protonated in the transient. However, rather surprisingly, the rate of elimination when $\mathrm{X}$ $=\mathrm{NH}_{3}{ }^{+}$is slower than for $\mathrm{X}=\mathrm{OH}$ or $\mathrm{H}_{2} \mathrm{O}^{+}$. A theoretical analysis suggests that these rates are correlated to the $\mathrm{C}-\mathrm{X}$ bond strengths [98].

The addition of ${ }^{\circ} \mathrm{CH}_{2} \mathrm{CMe}\left(\mathrm{NH}_{3}{ }^{+}\right)\left(\mathrm{COO}^{-}\right)$, generated from 2-methylalanine, equally leads to the rapid formation of an organocopper(II) transient, $\left[\mathrm{Cu}^{\mathrm{II}}-\mathrm{CH}_{2} \mathrm{CHMe}\left(\mathrm{NH}_{3}{ }^{+}\right)\left(\mathrm{COO}^{-}\right)\right]^{+}{ }_{\text {aq }}(k=(1.3 \pm$ 0.2) $10^{9} \mathrm{M}^{-1} \mathrm{~s}^{-1}$, much faster than the addition to $\mathrm{Cu}^{2+}$ aq (see section $\mathrm{B}$ ) [46]. This transient was found to decompose by two competitive pathways, one of which is $\beta$-elimination of ammonia (eq. (18), $\mathrm{X}=\mathrm{NH}_{3}$ ) with formation of the methacrylate ion, $\mathrm{CH}_{2}=\mathrm{CMeCOO}^{-}$, and the second is homolytic scission (eq. (21)) followed by trapping of the radical by the $\mathrm{Cu}^{2+}$ aq product of the first decomposition pathway, leading to the $\left[\mathrm{Cu}^{\mathrm{III}}-\mathrm{CH}_{2} \mathrm{CMe}\left(\mathrm{NH}_{3}{ }^{+}\right)\left(\mathrm{COO}^{-}\right)\right]^{2+}{ }_{\text {aq }}$ transient and ultimately to the same decomposition products observed when this ion is directly generated from $\mathrm{Cu}^{2+}$ (see section B. Using $\beta$-alanine, on the other hand, produced the ${ }^{\circ} \mathrm{CH}\left(\mathrm{COO}^{-}\right)_{2} \mathrm{CH}_{2}\left(\mathrm{NH}_{3}{ }^{+}\right)$radical. The resulting organocopper(II) adduct, $\left[\mathrm{Cu}^{\mathrm{II}}-\mathrm{CH}\left(\mathrm{COO}^{-}\right)_{2} \mathrm{CH}_{2}\left(\mathrm{NH}_{3}{ }^{+}\right)\right]^{+}$aq, equally decomposed by $\beta$ elimination of ammonia and formation of the acrylate ion [99].

\section{C.3. Reactions with ligand-stabilized $\mathrm{Cu}^{\mathrm{I}}$ systems}

The bis-adduct of $\mathrm{Cu}^{\mathrm{I}}$ with 1,10-phenantroline (phen), $\left[\mathrm{Cu}^{\mathrm{I}}(\mathrm{phen})_{2}\right]^{+}$, is a stable complex with no strong tendency to disproportionate and can be quantitatively obtained in situ by reduction of $\left[\mathrm{Cu}{ }^{\mathrm{II}} \text { (phen) }\right]^{2+}$ solutions with hydrazine. The generation of $\left[(\text { phen })_{2} \mathrm{Cu}^{\mathrm{II}}-\mathrm{CH}_{2} \mathrm{CR}_{2} \mathrm{OH}\right]^{+} \mathrm{R}=\mathrm{H}, \mathrm{Me}$ ) by reaction (16), the radicals being generated by pulse radiolysis of $\mathrm{N}_{2} \mathrm{O}$-saturated aqueous solutions containing $\mathrm{C}_{2} \mathrm{H}_{4}$ and $t \mathrm{BuOH}$, respectively, occurs very rapidly, too fast to yield a reliable rate constant (>10 $10 \mathrm{M}^{-1} \mathrm{~s}^{-1}$ ) [100]. These products decay by $\beta-\mathrm{OH}$ elimination with formation of ethylene and isobutene, according to eq. (18). The equilibrium constant for the $\mathrm{Cu}^{\mathrm{II}}-\mathrm{C}$ bond formation (eq. (16)) were estimated as $>6 \cdot 10^{6}$ for the $\mathrm{CH}_{2} \mathrm{CMe}_{2} \mathrm{OH}$ system and even larger for the $\mathrm{CH}_{2} \mathrm{CH}_{2} \mathrm{OH}$ system.

The dependence of the formation rate and decomposition mechanism of $\left[\mathrm{L} / \mathrm{Cu}{ }^{\mathrm{II}}-\mathrm{R}\right]$ on the nature of $\mathrm{R}$ and $\mathrm{L}$ was further investigated using $\mathrm{L}=\left(\mathrm{H}_{2} \mathrm{O}\right)_{\mathrm{n}}$ or 2,5,8,11-tetramethyl-2,5,8,11tetraazadodecane and $\mathrm{R}=\mathrm{CH}_{3}, \mathrm{CH}_{2} \mathrm{CO}_{2}^{-}, \mathrm{CHMeCO}_{2}^{-}$, or $\mathrm{CH}_{2} \mathrm{CH}_{2} \mathrm{CO}_{2}^{-}$[89]. The last two radicals form simultaneously from the pulse radiolysis in the presence of propionic acid at neutral $\mathrm{pH}$. The rates of formation (eq. (16)) are significantly slower for the complex with the tetraaza ligand (in the range $6 \cdot 10^{6}$ to $1 \cdot 10^{8} \mathrm{M}^{-1} \mathrm{~s}^{-1}$ ) relative to $\mathrm{Cu}^{+}$aq (in the range (2-4) $10^{9} \mathrm{M}^{-1} \mathrm{~s}^{-1}$ ). The relative rates vary with the nature of $\mathrm{R}$ in the order $\mathrm{CH}_{3}>\mathrm{CH}_{2} \mathrm{CO}_{2}^{-}>\mathrm{CH}_{2} \mathrm{CH}_{2} \mathrm{CO}_{2}^{-}>\mathrm{CHMeCO}_{2}^{-}$, the last radical reacting too slowly to afford a measurable rate. This suggests a main contribution of sterics on the observed rates. In terms of the decomposition, ethane was obtained for both systems when $\mathrm{R}=\mathrm{CH}_{3}$ by a second-order process without the involvement of free radicals, according to eq. (19). The reaction is much slower $\left(2 k=8.6 \cdot 10^{6} \mathrm{M}^{-1} \mathrm{~s}^{-1}\right)$ for the tetraaza complex than for the aqua complex $\left(2 k=3.0 \cdot 10^{8} \mathrm{M}^{-1} \mathrm{~s}^{-1}\right)$. The comparison between these two rate constants led the authors to prefer 
a mechanism via direct $\mathrm{C}-\mathrm{C}$ bond formation (transition state $\mathbf{C}$ in Scheme 5), whereas a greater rate difference would be expected in the other two cases.

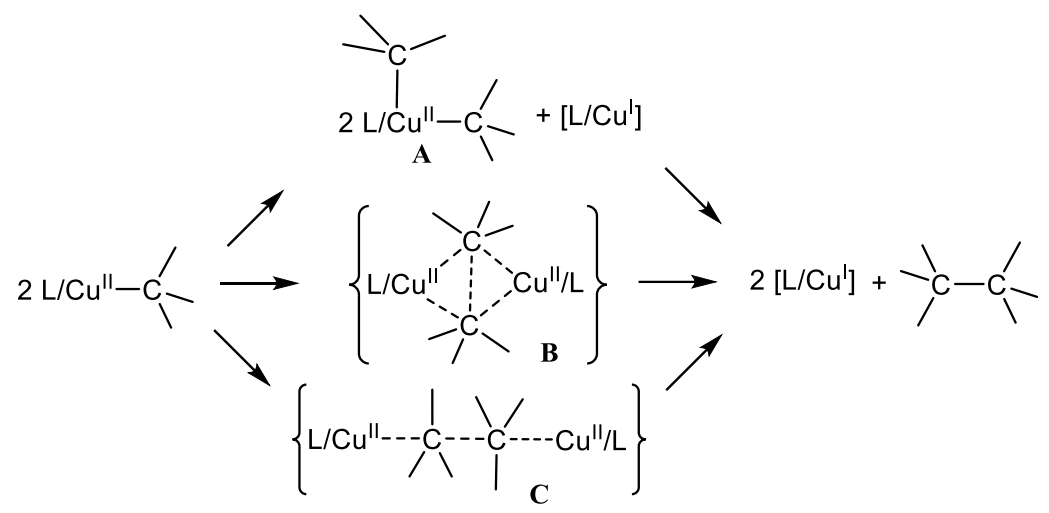

Scheme 5. Possible pathways for the bimolecular reductive elimination of [L/Cu$\left.{ }^{\mathrm{II}}-\mathrm{R}\right]$.

For $\mathrm{R}=\mathrm{CH}_{2} \mathrm{CH}_{2} \mathrm{CO}_{2}^{-}$, eq. (19) is also followed for the aqua complex, whereas homolysis with the production of radicals (eq. (21)) occurs for the complex with the tetraaza ligand as shown by the second-order dependence on organocopper species and the inverse dependence on $\left[\mathrm{L} / \mathrm{Cu}^{\mathrm{I}}\right]$. When $\mathrm{R}=\mathrm{CH}_{2} \mathrm{COOH}$ or $\mathrm{CHMeCOOH}$, on the other hand, protonolysis prevails for both systems (eq. (17)). This is attributed to the closer proximity of the electron-withdrawing $\mathrm{COOH}$ substituent, increasing the polarity of the $\mathrm{Cu}^{\mathrm{II}}-\mathrm{C}$ bond.

Another ligand that is able to stabilize $\mathrm{Cu}^{+}$in aqueous solution is carbon monoxide, yielding equilibria between different $\left[\mathrm{Cu}^{\mathrm{I}}(\mathrm{CO})_{n}\right]^{+}$species with $\mathrm{n}=1,3,4$ [101]. Pulse radiolysis in the presence of DMSO, which generated the ${ }^{\circ} \mathrm{CH}_{3}$ radical, of a solution where the $n=1$ species is prevalent yields $\left[(\mathrm{CO}) \mathrm{Cu}^{\mathrm{I}}-\mathrm{CH}_{3}\right]^{+}$with $k=(1.1 \pm 0.3) \cdot 10^{9} \mathrm{M}^{-1} \mathrm{~s}^{-1}$. This species decomposes by a first order process to yield $\mathrm{Cu}^{2+}{ }_{\text {aq }}$ and acetaldehyde. An alternative formulation of the radiolysis product as $\left[\mathrm{Cu}^{\mathrm{II}}-\mathrm{COCH}_{3}\right]^{+}$is excluded by the observation that the independent generation of this species from $\mathrm{Cu}^{+}$aq or $\left[\mathrm{Cu}^{\mathrm{I}}(\mathrm{CO})_{\mathrm{n}}\right]^{+}$and ${ }^{\circ} \mathrm{COCH}_{3}$, generated from acetaldehyde, yields a transient with a different absorption spectrum. The formation of $\left[\mathrm{Cu}^{\mathrm{II}}-\mathrm{COCH}_{3}\right]^{+}$by $\mathrm{CO}$ insertion from $\left[(\mathrm{CO}) \mathrm{Cu}^{\mathrm{I}}-\mathrm{CH}_{3}\right]^{+}$, however, is a prerequisite and is the rate-determining step in the degradation process, which is then completed by protonolysis (eq. (17)).

A most interesting way to generate an organocopper(II) species, which is quite relevant to OMRP and CRT, was recently introduced by Zerk and Bernhardt [102] making use of an electrochemical ATRP activation strategy for radical generation. The typical ATRP initiators ethyl 2bromoisobutyrate, bromoacetonitrile and chloroacetonitrile were used in this study. The active ATRP catalysts $\left[\mathrm{L} / \mathrm{Cu}^{\mathrm{I}}\right]^{+}(\mathrm{L}=$ TPMA, Me 6 TREN) were generated in situ by electrochemical reduction of the corresponding $\left[\mathrm{L} / \mathrm{Cu}^{\mathrm{II}} \mathrm{X}\right]^{+}$ions in cyclic voltammetric or spectroelectrochemical experiments with ultraviolet (UV)-visible and electron paramagnetic resonance (EPR) monitoring. More specifically, the investigated systems were $\left[\mathrm{TPMA} / \mathrm{Cu}{ }^{\mathrm{II}} \mathrm{Br}\right]^{+}+\mathrm{RBr}\left(\mathrm{R}=\mathrm{CMe}_{2}(\mathrm{COOMe})\right.$, $\left.\mathrm{CH}_{2} \mathrm{CN}\right)$ and $\left[\mathrm{Me}_{6} \mathrm{TREN} / \mathrm{Cu}^{\mathrm{II}} \mathrm{X}^{+}+\mathrm{XCH}_{2} \mathrm{CN}(\mathrm{X}=\mathrm{Cl}, \mathrm{Br})\right.$, using either DMSO or MeCN as solvents. In the cyclic voltammetry experiment, following the one-electron reduction of $\left[\mathrm{L} / \mathrm{Cu}{ }^{\mathrm{II}} \mathrm{X}\right]^{+}$, a new reduction wave at more negative potential, which is visible only in the presence of $\mathrm{RX}$, is attributed to the reduction of the $\left[\mathrm{L} / \mathrm{Cu}^{\mathrm{II}}-\mathrm{R}\right]^{+}$product formed by the sequence of reactions shown 
in Scheme 6. The starting $\left[\mathrm{L} / \mathrm{Cu}^{\mathrm{II}}-\mathrm{X}\right]^{+}$complex is first reduced, with loss of $\mathrm{X}^{-}$, at the potential $\mathrm{E}^{\circ} \mathrm{X}$, process (a). The electron addition and rapid $\mathrm{X}^{-}$loss yield a single wave for a coupled EC process). This generates the ATRP activator complex $\left[\mathrm{L} / \mathrm{Cu}^{\mathrm{I}}\right]^{+}$in situ within the diffusion layer. In a second process (b), the latter species activates RX to generate the free radical $\mathrm{R}^{*}$ by the typical ATRP activation process and reforms the deactivator complex $\left[\mathrm{L} / \mathrm{Cu}^{\mathrm{II}}-\mathrm{X}\right]^{+}$. The electrochemically generated $\left[\mathrm{L} / \mathrm{Cu}^{\mathrm{I}}\right]^{+}$complex, which is still the dominant species in the diffusion layer at $\mathrm{E}<\mathrm{E}^{\circ} \mathrm{X}$, traps the radical in the third step (equivalent to an OMRP deactivating process) to generate the organocopper(II) species [L/Cu$\left.{ }^{\mathrm{II}}-\mathrm{R}\right]^{+}$in process (c). The latter species, in a fourth step (d), is finally reduced to $\left[\mathrm{L} / \mathrm{Cu}^{\mathrm{I}}-\mathrm{R}\right]$ at the potential $\mathrm{E}^{\circ}$. Use of the tertiary radical generated from ethyl 2bromoisobutyrate did not lead to sufficiently stable $\left[\mathrm{L} / \mathrm{Cu}^{\mathrm{II}}-\mathrm{CMe}_{2}(\mathrm{COOEt})\right]^{+}$products (no appearance of the reduction wave at $\mathrm{E}_{\mathrm{R}}^{\circ}$ ), whereas a distinct reduction wave appears for the experiments carried out with the ATRP initiators chloro- and bromoacetonitrile, which generate $\left[\mathrm{L} / \mathrm{Cu}^{\mathrm{II}}-\mathrm{CH}_{2} \mathrm{CN}\right]^{+}$transients.

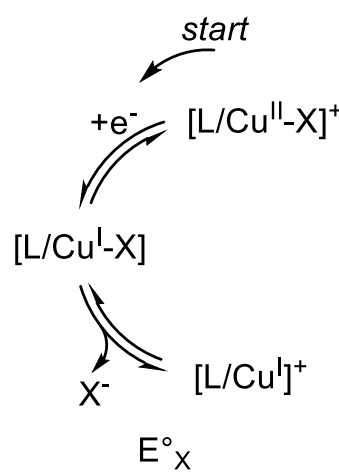

(a)

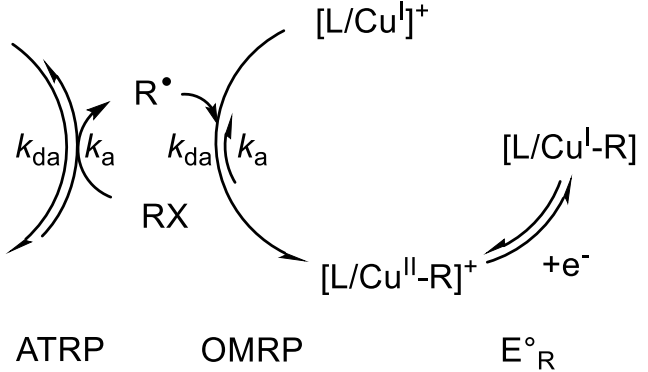

(b) (c)

Scheme 6. Formation of $\left[\mathrm{L} / \mathrm{Cu}^{\mathrm{II}}-\mathrm{R}\right]^{+}$species by electrochemically-induced radical generation from ATRP initiators.

The identity of the organocopper(II) species was confirmed by a spectroelectrochemical experiment, carried out for the [TPMA/Cu $\left.{ }^{\mathrm{II}}-\mathrm{Br}\right]^{+} / \mathrm{BrCH}_{2} \mathrm{CN}$ system by holding the potential at $\mathrm{E}^{\circ}{ }_{\mathrm{R}}$ $<\mathrm{E}<\mathrm{E}^{\circ} \mathrm{X}$. This resulted in the stoichiometry of eq. (27) and a change of the UV-visible absorption spectrum: the [TPMA/Cu $\left.{ }^{\mathrm{II}}-\mathrm{Br}\right]^{+}$band with $\lambda_{\max }>1000 \mathrm{~nm}$ was replaced with a new band with $\lambda_{\max }$ $=750 \mathrm{~nm}$. The presence of an isosbestic point demonstrated the relative stability of the final product, which was further confirmed by EPR spectroscopy. Other formulations for the new species, such as a hydride complex $\left[\mathrm{TPMA} / \mathrm{Cu}^{\mathrm{II}}-\mathrm{H}\right]^{+}$or a neutral halide adduct [TPMA/Cu ${ }^{\mathrm{II}}(\mathrm{Br})\left(\mathrm{CH}_{2} \mathrm{CN}\right)$ ], could be excluded.

$$
\left[\mathrm{TPMA} / \mathrm{Cu}{ }^{\mathrm{II}}-\mathrm{Br}\right]^{+}+\mathrm{R}-\mathrm{Br}+2 \mathrm{e}^{-} \rightarrow\left[\mathrm{TPMA} / \mathrm{Cu}^{\mathrm{II}}-\mathrm{CH}_{2} \mathrm{CN}\right]^{+}+2 \mathrm{Br}^{-}
$$

As far as polymerization systems are concerned, evidence for the formation of organocopper(II) where the growing radical chain is bonded to the $\mathrm{Cu}^{\mathrm{II}}$ ion goes back to a report by Matyjaszewski and Woodworth on the polymerization of styrene and methyl acrylate initiated by AIBN in the 
presence of $\mathrm{L} / \mathrm{Cu}^{\mathrm{I}}$ and $\mathrm{L} / \mathrm{Cu}^{\mathrm{II}}$ triflates, where $\mathrm{L}$ is a substituted 2,2'-bipyridine (bpy) ligand and in the absence of halides (OMRP conditions). While $\mathrm{Cu}^{\mathrm{II}}$ had no noticeable effect on the polymerization rate, the presence of $\mathrm{Cu}^{\mathrm{I}}$ significantly retarded the MA (but not the styrene) polymerization. These results were taken as evidence that the poly(methyl acrylate) radical chains interact with the $\mathrm{Cu}^{\mathrm{I}}$ (but not with the $\mathrm{Cu}^{\mathrm{II}}$ ion), leading to the formation of an organocopper(II) dormant species. The effect is to reduce the free radical concentration by the OMRP equilibrium (Scheme 2), thus slowing down the polymerization.

Subsequent work led to the discovery of the CRT phenomenon. Under conditions where excess radicals with respect to the amount of $\mathrm{L} / \mathrm{Cu}^{\mathrm{I}}$ were produced, the radical termination rate increased. Various ligands, shown in Figure 7 and Figure 8, were tested and proved to strongly affect the CRT activity $\left(\mathrm{BPMA}^{\mathrm{Me}}\left(\sim\right.\right.$ no activity) $\left.<\mathrm{BPMA}^{* \mathrm{Pr}} \sim \mathrm{TPMA}<\mathrm{TPMA}^{* 1}<\mathrm{TPMA}^{* 2}<\mathrm{TPMA}^{* 3}\right)[82$, 84] The activity in CRT scales with the electrochemical reduction potential and with the ATRP activity and is not strongly influenced by the ligand denticity (tridentate vs. tetradentate) as demonstrated by the BPMA*Pr-TPMA comparison, although the kinetic analysis revealed that a denticity change altered the rate-determining step of the CRT process under these conditions. The possible involvement of a hydride intermediate, which would lead to termination by disproportionation by a mechanism related to that of catalytic chain transfer [103], was excluded by a computational study [83] while the key role of organocopper(II) species is consistent with the correlation of the CRT activity with the calculated bond strength of the $\mathrm{L} / \mathrm{Cu}^{\mathrm{II}}-\mathrm{R}$ bond $(\mathrm{R}=$ $\mathrm{CHMe}(\mathrm{COOMe})$, molecular model of a PMA chain) [84]. However, no clear experimental evidence could be obtained for the generation of this organometallic species in these polymerization studies.
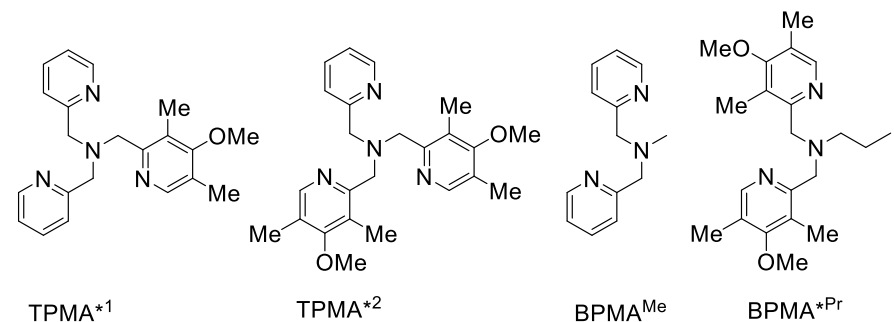

BPMA $^{\mathrm{Me}}$

$\mathrm{BPMA}^{* \mathrm{Pr}}$

Figure 8. Ligands used for the investigation of $\mathrm{Cu}$-catalyzed radical termination.

Direct evidence was obtained later by EPR spectroscopy on the basis of a time-resolved singlepulse pulsed laser polymerization (SP-PLP) experiment [104]. Primary radicals were photogenerated by the laser pulse from $\alpha$-methyl-4-(methylmercapto)- $\alpha$-morpholinopropiophenone and allowed to initiate the polymerization of $n$-butyl acrylate (BA) to generate poly(butyl acrylate) radicals chains ( $\mathrm{PBA}^{\circ}$ ), see Scheme 7 . The rate of disappearance of these radicals was then measured by EPR spectroscopy in the absence and presence of $\mathrm{L} / \mathrm{Cu}^{\mathrm{I}}$ at $-40^{\circ} \mathrm{C}$, a temperature chosen to avoid the occurrence of back-biting, which would produce less reactive mid-chain tertiary radicals. In the absence of $\mathrm{L} / \mathrm{Cu}^{\mathrm{I}}$, the $\mathrm{PBA}{ }^{\circ}$ radicals disappeared by the standard bimolecular radical termination. In the presence of $\mathrm{L} / \mathrm{Cu}^{\mathrm{I}}$ complexes, on the other hand, a faster rate of disappearance obeying a first-order dependence in radicals and first-order in $\left[\mathrm{Cu}^{\mathrm{I}}\right]$ generated a new 
distinct EPR signal attributed to the [L/Cu ${ }^{\text {II }-P B A] ~ t r a n s i e n t, ~ w h i c h ~ a c c u m u l a t e d ~ a s ~ a ~ r e l a t i v e l y ~}$ stable species at $-40^{\circ} \mathrm{C}$. The rate constant of the addition process could be determined as $(3.0 \pm 0.8) \cdot 10^{5}$, and $(9 \pm 3) \cdot 10^{3} \quad \mathrm{M}^{-1} \mathrm{~s}^{-1}$ for $\mathrm{L}=$ TPMA and $N, N, N$, $N$ '”, $N$ "'pentamethyldiethylenetriamine, while for $\mathrm{L}=N, N, N$,,$N$,", $N$, ',,$N$, ',-hexamethyltriethylenetetraamine this constant was too low for an accurate determination by this technique. These adducts decomposed upon warming to $0^{\circ} \mathrm{C}$. For comparison, the rate constants for the corresponding ATRP deactivations $\left(\mathrm{Br}\right.$ atom transfers from [L/Cu ${ }^{\mathrm{II}}-\mathrm{Br}$ ] where measured as $(0.9 \pm 0.2) \cdot 10^{6}$, and $(6 \pm 2) \cdot 10^{6}$ and $(2.0 \pm 0.5) \cdot 10^{6} \mathrm{M}^{-1} \mathrm{~s}^{-1}$ in similar SP-PLP experiments conducted in the presence of copper(II) complexes with the same three ligands. The comparison shows that, for these complexes and polymer chain, the OMRP deactivation (Scheme 2) is slower than the ATRP deactivation (Scheme 1) and more strongly influenced by the ligand nature. The EPR signature of these species is different than, but shows similar parameters to that of [L/Cu $\left.{ }^{\mathrm{II}}-\mathrm{Br}\right]$. This transient decomposed at higher temperature, to regenerate the $\mathrm{L} / \mathrm{Cu}^{\mathrm{I}}$ precursor plus terminated macromolecules. It is to be noted that all these CRT investigations were conducted in $\mathrm{MeCN}$ as solvent. As already shown above, EPR spectroscopic evidence for the generation of a [L/Cu $\left.{ }^{\mathrm{II}}-\mathrm{R}\right]$ species was also obtained in an electrochemical investigation conducted on a molecular model [102].

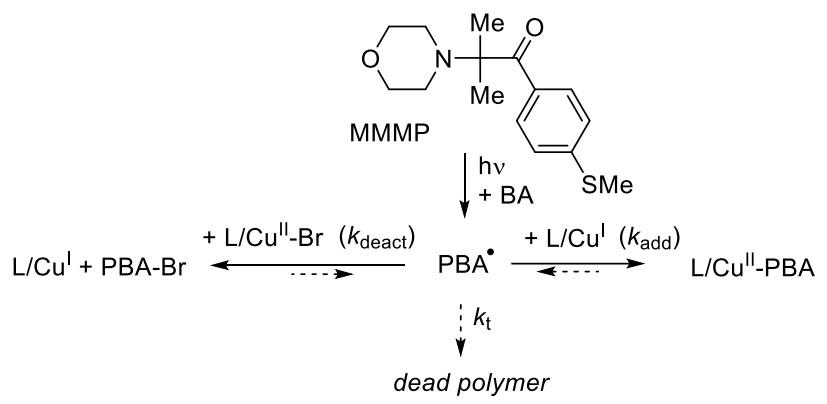

Scheme 7. Chemical changes in the SP-PLP study of $\alpha$-methyl-4-(methylmercapto)- $\alpha$ morpholinopropiophenone/BA in the absence or presence of $\mathrm{L} / \mathrm{Cu}^{\mathrm{I}}$ or $\mathrm{L} / \mathrm{Cu}^{\mathrm{II}}-\mathrm{Br}$ complexes.

An additional recent study, aimed at determining the nature of the polymer chain ends, has provided some insight onto the CRT mechanism. An ATRP macroinitiator $\mathrm{MeCH}(\mathrm{COOEt})-\mathrm{MA} \mathrm{n}-\mathrm{Br}(\mathrm{n} \sim 30)$ with a narrow molecular weight distribution was activated in $\mathrm{MeCN}$ by $\left[\mathrm{Cu}^{\mathrm{I}}(\mathrm{TPMA})\right][\mathrm{Br}]$ and allowed to terminate under conditions that maximize CRT relative to conventional bimolecular terminations [105]. The resulting polymer was then analyzed by size exclusion chromatography, by ${ }^{1} \mathrm{H}$ NMR and by matrix-assisted laser-desorption ionization - time of flight mass spectrometry. Standard radical terminations by coupling would lead to chains with a double average degree of polymerization and two $\mathrm{MeCH}(\mathrm{COOEt})$ chain ends, $\mathrm{MeCH}(\mathrm{COOEt})-\mathrm{MA}_{2 \mathrm{n}}-\mathrm{CH}(\mathrm{COOEt}) \mathrm{Me}$, whereas termination by disproportionation would give a 1:1 ratio of $\mathrm{MeCH}(\mathrm{COOEt})-\mathrm{MA}_{\mathrm{n}}-\mathrm{H}$ and $\mathrm{MeCH}(\mathrm{COOEt})-\mathrm{MA}_{\mathrm{n}-1}-\mathrm{CH}=\mathrm{CH}(\mathrm{COOEt})$ chains. Instead, only $\mathrm{MeCH}(\mathrm{COOEt})-\mathrm{MA}_{\mathrm{n}}-\mathrm{H}$ chains were detected. Termination of an equivalent $\mathrm{MeCH}(\mathrm{COOEt})-\left(\mathrm{d}_{3}-\mathrm{MA}\right)_{\mathrm{n}}-\mathrm{Br}$ macroinitiator, where the monomer was selectively deuterated at the backbone positions $\left(\mathrm{CD}_{2}=\mathrm{CD}-\mathrm{COOCH}\right)$, gave $\mathrm{MeCH}(\mathrm{COOEt})-\left(\mathrm{d}_{3}-\mathrm{MA}\right)_{\mathrm{n}}-\mathrm{H}$ with no unsaturations and no deuterium incorporation at the chain ends, pointing to the $\mathrm{MeCN}$ solvent as a possible source of the chain end $\mathrm{H}$ atom by hydrogen atom transfer. However, adventitious moisture in the monomer or solvent has also been invoked as a 
possible source of the terminal $\mathrm{H}$ atom by protonolysis of the organometallic intermediate. Work is still ongoing in our laboratories to elucidate the origin of this $\mathrm{H}$ atom and the mechanism of the CRT process.

In closing this section, it should also be mentioned that organocopper(II) intermediates can also be formed by photolysis of stable alkene complexes of $\mathrm{Cu}^{\mathrm{I}}$. For instance, photolysis of an ethylenesaturated $\mathrm{MeOH}$ solution of $\left[\mathrm{Cu}^{\mathrm{I}}\left(\mathrm{C}_{2} \mathrm{H}_{4}\right)\right]^{+}$was proposed to yield the diradical intermediate $\left[\mathrm{Cu}^{\mathrm{II}}-\right.$ $\left.\mathrm{CH}_{2} \mathrm{CH}_{2}{ }^{\circ}\right]^{+}$, which then proceeds under these conditions to yield hexane and formaldehyde [106]. The overall process is a photocatalyzed conversion of ethylene to hexane and formaldehyde by a radical mechanism.

\section{C.4. Isolated organocopper(II) complexes}

Given the variety of favorable decomposition pathways (eq. (17)-(20)) and the homolytic weakness of the $\mathrm{Cu}^{\mathrm{II}}-\mathrm{C}$ bond (eq. (21)), organocopper(II) compounds that are sufficiently stable to allow their isolation and full characterization are rare, even more that those of $\mathrm{Cu}^{\mathrm{III}}$ described in section B.4. In a few cases, the $\mathrm{Cu}$-bonded $\mathrm{C}$ atom is incorporated in a multidentate ligand that sterically or electronically (e.g. by electron delocalization) protects the $\mathrm{C}$ atom from the degradative reaction pathways. Examples of this kinds, stabilized by "confused porphyrin" scaffolds, are shown in Figure 9. An early example is provided by system $12(\mathrm{R}=\mathrm{H}, \mathrm{Me})$, which was fully characterized only in solution [74, 107, 108]. All other compounds in Figure 9 were structurally characterized by X-ray diffraction.

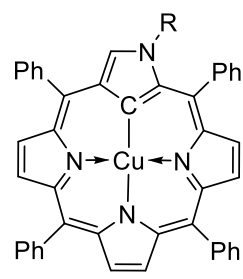

12

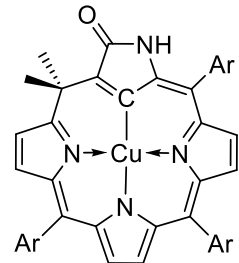

13

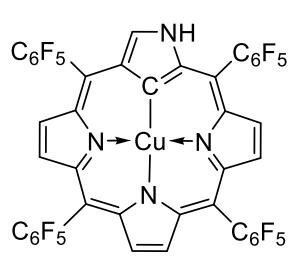

14

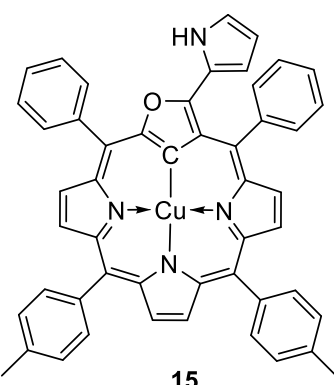

15

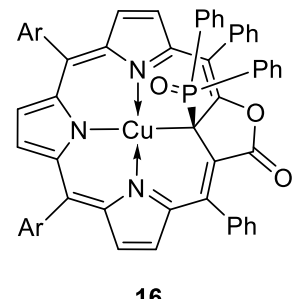

16

Figure 9. A few isolated organocopper(II) compounds with the $\mathrm{Cu}$-bonded $\mathrm{C}$ atom incorporated in confused porphyrin rings.

Compound $\mathbf{1 3}$ is a square-planar complex with a calix[4]phyrin ring [109]. Compound $\mathbf{1 4}$ has a very similar structure in which the $\mathrm{N}$-confused porphyrin is not oxidized and remains fully conjugated [110]. The presence of the electron withdrawing $\mathrm{C}_{6} \mathrm{~F}_{5}$ substituents in the ring meso positions is essential for stabilization, as the equivalent phenyl-substituted $\mathrm{N}$-confused porphyrin complex was described as too unstable for isolation. Compound 15, containing an O-confused porphyrin, was obtained by ligand oxidation from the related organocopper(III) derivative described in section B.4 [75]. In compound 16 containing the 21-diphenylphosphoryl-carbaporpholactone ligand, the $\mathrm{Cu}$-bonded $\mathrm{C}$ atom has an $\mathrm{sp}^{3}$ hybridization [111].

A few $\mathrm{Cu}^{\mathrm{II}}$ complexes feature a bond to a $\mathrm{C}$ atom incorporated into an $\mathrm{N}$-heterocyclic carbene ligand, see Figure 10 for a few examples. These are 2-electron donor ligands and are not added as the corresponding C-based radical. 


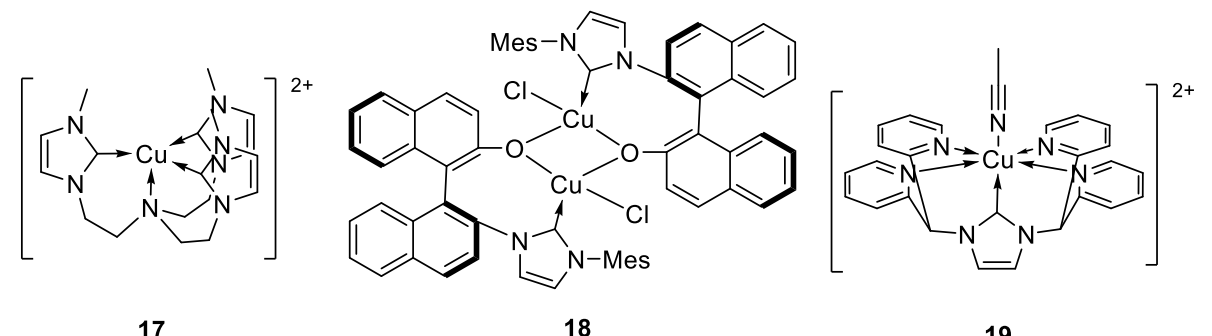

17

18

19

Figure 10. Selected examples of copper(II) complexes containing $\mathrm{Cu}-\mathrm{C}$ bonds to $\mathrm{N}$-heterocyclic carbene ligands: 17 [112], 18 [113], 19 [114].

Incorporation of the $\sigma$ - bonded $\mathrm{sp}^{3} \mathrm{C}$ atom into the tripodal ligand TPDM provides kinetic stabilization. A series of stable trigonal bipyramidal complexes $\mathbf{2 0}$ could be isolated and characterized, see Figure 11. The cationic complex with $\mathrm{X}=\mathrm{MeCN}$ [115] and the neutral ones with $\mathrm{X}=\mathrm{F}$ or I [116] were characterized by X-ray diffraction. These compounds show reversible oneelectron oxidations; for the chloride derivative, a stable cationic $\mathrm{Cu}^{\mathrm{III}}$ has been isolated and structurally characterized, as described above in section B.4.

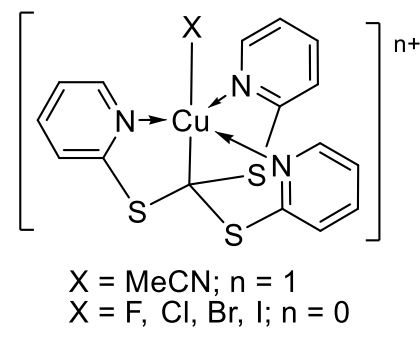

20

Figure 11. Stable copper(II) complexes with bonds to the $\mathrm{sp}^{3}$-hybridized $\mathrm{C}$ atom incorporated in the tripodal TPDM ligand [115-117].

Finally, a most interesting example of a stable, fully characterized organocopper(II) complex, 21, contains cyanomethyl as a monodentate carbyl ligand in a square planar geometry, see Figure 12 [118]. This is a rather remarkable compound because the cyanomethyl group is highly stabilized as a free radical, thus the $\mathrm{Cu}-\mathrm{C}$ bond is expected to be homolytically weak, and because the $\mathrm{Cu}$ $\mathrm{CH}_{2} \mathrm{CN}$ moiety lacks the kinetic stabilization of the chelating effect. Possible stabilizing factors for this compound are the presence of the dianionic diamidopyridine pincer ligand, which is known to impart electronic stabilization to higher oxidation states, and the steric protection provided by the two wingtip xylyl groups. The compound derives from an unexpected proton transfer reaction from the corresponding $\left[\mathrm{L} / \mathrm{Cu}^{\mathrm{II}}(\mathrm{OH})\right]^{-}$complex and $\mathrm{MeCN}$, yielding $\left[\mathrm{L} / \mathrm{Cu}^{\mathrm{II}}\left(\mathrm{CH}_{2} \mathrm{CN}\right)\right]^{-}$and water. The mechanism appears to involve a pre-equilibrium of $\mathrm{MeCN}$ coordination followed by ratedetermining proton transfer, as shown in Figure 12. This is suggested by the zero-order dependence in $[\mathrm{MeCN}]$ and by a kinetic isotope effect of 4.1(1), in comparison with the corresponding reaction carried out with $\mathrm{CD}_{3} \mathrm{CN}$. Another interesting feature of compound 21 is a pseudoreversible oxidation wave in cyclic voltammetry to yield a neutral $\left[\mathrm{L} / \mathrm{Cu}^{\mathrm{III}}-\mathrm{CH}_{2} \mathrm{CN}\right]$ product, which was however stable only at $-30^{\circ} \mathrm{C}$ and could not be isolated [118]. Another related organocopper(II) complex with a monodentate $\mathrm{CH}_{2} \mathrm{CN}$ group is [TPMA/Cu ${ }^{\mathrm{II}}-\mathrm{CH}_{2} \mathrm{CN}$ ], with a presumed trigonal 
bipyramidal structure, already discussed in the previous section [102]. This compound, however, in spite of its apparent stability as indicated by the UV-visible and EPR characterization, was not isolated and structurally characterized.
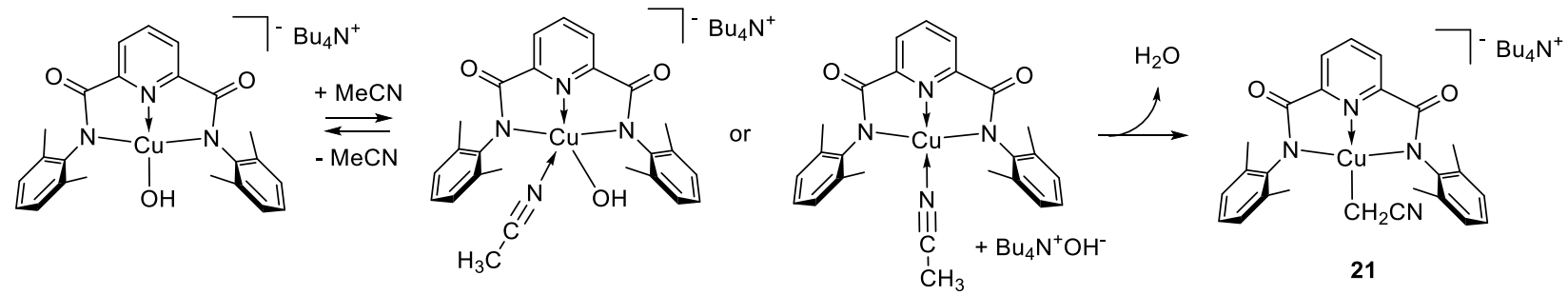

Figure 12. Formation of an organocopper(II) complex with a bond to an $\mathrm{sp}^{3}$-hybridized monodentate carbyl ligand [118].

\section{Conclusions}

All the research work reviewed here has amply demonstrated that organocopper(II) and -(III) species may be generated when carbon-centered radicals are produced in the presence of $\mathrm{Cu}^{\mathrm{I}}$ or $\mathrm{Cu}^{\mathrm{II}}$ ions, respectively. These alkylcopper species typically display a high reactivity and decay by a variety of processes, depending on the nature of the radical and metal coordination sphere (homolytic strength and polarity of the $\mathrm{Cu}-\mathrm{C}$ bond, steric labilization) and on the chemical environment (nature of the solvent, presence and concentration of metals or protic reagents, $\mathrm{pH}$, etc.). The ligand environment strongly affects the decay rate and mechanism. When all the decay pathways are rendered ineffective, the complexes become sufficiently stable and may be isolated or fully characterized in solution. These transients appear to be involved in a variety of coppercatalyzed organic transformations. The generation of organocopper(II) intermediates as a side process in the ubiquitous $\mathrm{Cu}^{\mathrm{I}}$-catalyzed atom transfer radical polymerization, specifically for acrylate monomers, leads to loss of chain-end functionality by catalyzed radical termination. The latter process appears so far specific for processes conducted in $\mathrm{MeCN}$ solutions and involves the activation of the solvent $\mathrm{C}-\mathrm{H}$ bond by coordination, followed by a hydrogen atom transfer to produce macromolecules with a saturated chain end.

\section{E. Acknowledgment}

We wish to acknowledge support from the NSF (CHE 1707490), the Centre National de la Recherche Scientifique (CNRS) (PICS06782 and LIA "Laboratory of Coordination Chemistry for Controlled Radical Polymerization") the French Embassy in Washington D.C. (Chateaubriand Fellowship to TGR) and the CMU Department of Chemistry (Harrison Fellowship to TGR). We are also grateful to GENCI (Grand Equipement National de Calcul Intensif) and to CICT (Centre Interuniversitaire de Calcul de Toulouse) for the allocation of computational resources (IDRIS 086343 and CALMIP P0402, respectively). 


\section{F. List of abbreviations}

$\begin{array}{ll}\text { ATRA } & \text { atom transfer radical additions } \\ \text { ATRP } & \text { atom transfer radical polymerization } \\ \text { BA } & \text { butyl acrylate } \\ \text { CRT } & \text { catalyzed radical termination } \\ \text { EPR } & \text { electron paramagnetic resonance } \\ \text { ISET } & \text { inner-sphere electron transfer } \\ \text { MA } & \text { methyl acrylate } \\ \text { Me6TREN } & \text { tris(2-dimethylaminoethyl)amine } \\ \text { NMR } & \text { nuclear magnetic resonance } \\ \text { OMRP } & \text { organometallic-mediated radical polymerization } \\ \text { phen } & 1,10 \text {-phenantroline } \\ \text { PBA } & \text { poly(butyl acrylate) } \\ \text { PMA } & \text { poly(methyl acrylate) } \\ \text { RDRP-RT } & \text { reversible deactivation radical polymerization - reversible termination } \\ \text { SP-PLP } & \text { single-pulse pulsed laser polymerization } \\ \text { TPDM } & \text { tris(2-pyridylthio)methane } \\ \text { TPMA } & \text { tris(2-pyridylmethyl)amine } \\ \text { TPMA*3 } & \text { tris(3,5-dimethyl-4-methoxy-2-pyridylmethyl)amine } \\ \text { UV } & \text { ultraviolet }\end{array}$

\section{G. References}

[1] R.J.K. Taylor, Organocopper Reagents, A Practical Approach, Oxford University Press, Oxford, 1994.

[2] N. Krause, Modern Organocopper Chemistry, Wiley-VCH, Weinheim, 2002.

[3] Z. Rappoport, I. Marek, The Chemistry of Organocopper Compounds, Wiley, Chichester, 2009.

[4] N. Yoshikai, E. Nakamura, Chem. Rev., 112 (2012) 2339-2372.

[5] K.W. Shimkin, D.A. Watson, Beilstein Journal of Organic Chemistry, 11 (2015) 2278-2288.

[6] G.-B. Li, C. Zhang, C. Song, Y.-D. Ma, Beilstein Journal of Organic Chemistry, 14 (2018) 155-181.

[7] T. Pintauer, K. Matyjaszewski, Chem. Soc. Rev., 37 (2008) 1087-1097.

[8] O. Reiser, Acc. Chem. Res., 49 (2016) 1990-1996.

[9] A.J. Clark, Eur. J. Org. Chem., (2016) 2231-2243.

[10] A.E. Wendlandt, A.M. Suess, S.S. Stahl, Angew. Chem. Int. Ed., 50 (2011) 11062-11087.

[11] X.-Q. Chu, D. Ge, Z.-L. Shen, T.-P. Loh, ACS Catal., 8 (2018) 258-271.

[12] D.A. Petrone, J.T. Ye, M. Lautens, Chem. Rev., 116 (2016) 8003-8104.

[13] X.W. Lan, N.X. Wang, Y.L. Xing, Eur. J. Org. Chem., (2017) 5821-5851.

[14] S. Oikawa, S. Kawanishi, Biochemistry, 35 (1996) 4584-4590.

[15] Y. Hiraku, S. Kawanishi, Cancer Research, 56 (1996) 1786-1793.

[16] N. Kashige, T. Takeuchi, S. Matsumoto, S. Takechi, F. Miake, T. Yamaguchi, Biological \& Pharmaceutical Bulletin, 28 (2005) 419-423.

[17] C. Chatgilialoglu, C. Ferreri, K. Matyjaszewski, Chempluschem, 81 (2016) 11-29. 
[18] K. Matyjaszewski, Macromolecules, 45 (2012) 4015-4039.

[19] H. Fischer, Chem. Rev., 101 (2001) 3581-3610.

[20] R. Poli, Angew. Chem. Int. Ed., 45 (2006) 5058-5070.

[21] R. Poli, Organometallic Mediated Radical Polymerization, in: K. Matyjaszewski, M. Möller (Eds.) Polymer Science: A Comprehensive Reference, Elsevier BV, Amsterdam, 2012, pp. 351375.

[22] A. Debuigne, R. Poli, C. Jérôme, R. Jérome, C. Detrembleur, Prog. Polym. Sci., 34 (2009)

211-239.

[23] R. Poli, Chem. Eur. J., 21 (2015) 6988-7001.

[24] C.Y. Lin, S.R.A. Marque, K. Matyjaszewski, M.L. Coote, Macromolecules, 44 (2011) 75687583.

[25] K. Matyjaszewski, J.H. Xia, Chem. Rev., 101 (2001) 2921-2990.

[26] M. Kamigaito, T. Ando, M. Sawamoto, Chem. Rev., 101 (2001) 3689-3745.

[27] M. Ouchi, T. Terashima, M. Sawamoto, Chem. Rev., 109 (2009) 4963-5050.

[28] F. di Lena, K. Matyjaszewski, Progr. Polym. Sci., 35 (2010) 959-1021.

[29] K. Matyjaszewski, Israel Journal of Chemistry, 52 (2012) 206-220.

[30] K. Matyjaszewski, J. Spanswick, Atom Transfer Radical Polymerization (ATRP), in:

Reference Module in Materials Science and Materials Engineering, Elsevier, 2016.

[31] J.K. Kochi, A. Bemis, C.L. Jenkins, J. Am. Chem. Soc., 90 (1968) 4616-4625.

[32] C.L. Jenkins, J.K. Kochi, J. Am. Chem. Soc., 94 (1972) 843-855.

[33] C. Walling, S. Kato, J. Am. Chem. Soc., 93 (1971) 4275-4281.

[34] C.L. Jenkins, J.K. Kochi, J. Am. Chem. Soc., 94 (1972) 856-865.

[35] K. Matyjaszewski, B.E. Woodworth, Macromolecules, 31 (1998) 4718-4723.

[36] J.F. Lutz, K. Matyjaszewski, J. Polym. Sci., Polym. Chem., 43 (2005) 897-910.

[37] M. Tamura, J.K. Kochi, J. Org. Chem., 42 (1972) 205-228.

[38] M. Freiberg, D. Meyerstein, Chem. Commun., (1977) 127-128.

[39] H. Cohen, D. Meyerstein, J. Am. Chem. Soc., 94 (1972) 6944-6948.

[40] J.K. Kochi, Acc. Chem. Res., 7 (1974) 351-360.

[41] H. Cohen, D. Meyerstein, Inorg. Chem., 25 (1986) 1505-1506.

[42] G.V. Buxton, J.C. Green, Journal of the Chemical Society-Faraday Transactions I, 74 (1978) 697-714.

[43] M. Freiberg, D. Meyerstein, Journal of the Chemical Society-Faraday Transactions I, 76 (1980) 1825-1837.

[44] G.R.A. Johnson, N.B. Nazhat, Journal of the Chemical Society-Faraday Transactions I, 80

(1984) 3455-3462.

[45] M. Masarwa, H. Cohen, J. Saar, D. Meyerstein, Israel Journal of Chemistry, 30 (1990) 361368.

[46] S. Goldstein, G. Czapski, H. Cohen, D. Meyerstein, Inorg. Chem., 31 (1992) 2439-2444.

[47] G. Ferraudi, Inorg. Chem., 17 (1978) 2506-2508.

[48] T.S. Roche, J.F. Endicott, Inorg. Chem., 13 (1974) 1575-1580.

[49] M. Masarwa, H. Cohen, D. Meyerstein, Inorg. Chem., 25 (1986) 4897-4900.

[50] W.A. Mulac, D. Meyerstein, Chem. Commun., (1979) 893-895.

[51] L.J. Kirschenbaum, D. Meyerstein, Inorg. Chem., 19 (1980) 1373-1379.

[52] C. Mansano-Weiss, D.M. Epstein, H. Cohen, A. Masarwa, D. Meyerstein, Inorg. Chim. Acta, 339 (2002) 283-291.

[53] G.R.A. Johnson, N.B. Nazhat, R.A. Saadalla-Nazhat, Journal of the Chemical Society-

Faraday Transactions I, 85 (1989) 677-689. 
[54] M. Masarwa, H. Cohen, R. Glaser, D. Meyerstein, Inorg. Chem., 29 (1990) 5031-5035.

[55] G.S. Reddy, G.G. Smith, Inorg. Chim. Acta, 133 (1987) 1-2.

[56] A. Burg, Y. Wolfer, H. Kornweitz, L. Shenar-Jackson, A. Masarwa, D. Meyerstein, Dalton Trans., 42 (2013) 4985-4993.

[57] C. Sambiagio, S.P. Marsden, A.J. Blacker, P.C. McGowan, Chem. Soc. Rev., 43 (2014) 3525-3550.

[58] H. Miyabe, Eur. J. Org. Chem., (2017) 3302-3310.

[59] J. Rong, C.F. Ni, J.B. Hu, Asian Journal of Organic Chemistry, 6 (2017) 139-152.

[60] M.A. Willert-Porada, D.J. Burton, N.C. Baenziger, Chem. Commun., (1989) 1633-1634.

[61] D. Naumann, T. Roy, K.F. Tebbe, W. Crump, Angew. Chem. Int. Ed., 32 (1993) 1482-1483.

[62] R. Eujen, B. Hoge, D.J. Brauer, J. Organomet. Chem., 519 (1996) 7-20.

[63] S.H. Bertz, S. Cope, D. Dorton, M. Murphy, C.A. Ogle, Angew. Chem. Int. Ed., 46 (2007) $7082-7085$.

[64] S.H. Bertz, S. Cope, M. Murphy, C.A. Ogle, B.J. Taylor, J. Am. Chem. Soc., 129 (2007) 7208-7209.

[65] T. Gaertner, W. Henze, R.M. Gschwind, J. Am. Chem. Soc., 129 (2007) 11362-+.

[66] S.H. Bertz, M.D. Murphy, C.A. Ogle, A.A. Thomas, Chem. Commun., 46 (2010) 1255-

1256.

[67] E.R. Bartholomew, S.H. Bertz, S. Cope, D.C. Dorton, M. Murphy, C.A. Ogle, Chem.

Commun., (2008) 1176-1177.

[68] E.R. Bartholomew, S.H. Bertz, S. Cope, M. Murphy, C.A. Ogle, J. Am. Chem. Soc., 130 (2008) 11244-11245.

[69] H. Hu, J.P. Snyder, J. Am. Chem. Soc., 129 (2007) 7210-+.

[70] E.R. Bartholomew, S.H. Bertz, S.K. Cope, M.D. Murphy, C.A. Ogle, A.A. Thomas, Chem. Commun., 46 (2010) 1253-1254.

[71] H. Furuta, H. Maeda, A. Osuka, J. Am. Chem. Soc., 122 (2000) 803-807.

[72] H. Maeda, A. Osuka, H. Furuta, J. Am. Chem. Soc., 125 (2003) 15690-15691.

[73] K. Araki, H. Winnischofer, H.E. Toma, H. Maeda, A. Osuka, H. Furuta, Inorg. Chem., 40 (2001) 2020-2025.

[74] H. Maeda, Y. Ishikawa, T. Matsuda, A. Osuka, H. Furuta, J. Am. Chem. Soc., 125 (2003) 11822-11823.

[75] M. Pawlicki, I. Kanska, L. Latos-Grazynski, Inorg. Chem., 46 (2007) 6575-6584.

[76] X. Ribas, D.A. Jackson, B. Donnadieu, J. Mahia, T. Parella, R. Xifra, B. Hedman, K.O.

Hodgson, A. Llobet, T.D.P. Stack, Angew. Chem. Int. Ed., 41 (2002) 2991-2994.

[77] R. Xifra, X. Ribas, A. Llobet, A. Poater, M. Duran, M. Sola, T.D.P. Stack, J. Benet-

Buchholz, B. Donnadieu, J. Mahia, T. Parella, Chem. Eur. J., 11 (2005) 5146-5156.

[78] A. Casitas, A.E. King, T. Parella, M. Costas, S.S. Stahl, X. Ribas, Chemical Science, 1 (2010) 326-330.

[79] B. Yao, D.-X. Wang, Z.-T. Huang, M.-X. Wang, Chem. Commun., (2009) 2899-2901.

[80] R. Santo, R. Miyamoto, R. Tanaka, T. Nishioka, K. Sato, K. Toyota, M. Obata, S. Yano, I.

Kinoshita, A. Ichimura, T. Takui, Angew. Chem. Int. Ed., 45 (2006) 7611-7614.

[81] K. Schröder, D. Konkolewicz, R. Poli, K. Matyjaszewski, Organometallics, 31 (2012) $7994-$ 7999.

[82] Y. Wang, N. Soerensen, M. Zhong, H. Schroeder, M. Buback, K. Matyjaszewski, Macromolecules, 46 (2013) 683-691.

[83] S.M.W. Rahaman, K. Matyjaszewski, R. Poli, Polym. Chem., 7 (2016) 1079-1087. 
[84] T.G. Ribelli, S.M.W. Rahaman, J.-C. Daran, P. Krys, K. Matyjaszewski, R. Poli, Macomolecules, 49 (2016) 7749-7757.

[85] T.G. Ribelli, K.F. Augustine, M. Fantin, P. Krys, R. Poli, K. Matyjaszewski, Macromolecules, 50 (2017) 7920-7929.

[86] Y. Nakamura, T. Ogihara, S. Yamago, ACS Macro Lett., 5 (2016) 248-252.

[87] N.A. Clinton, J.K. Kochi, J. Organomet. Chem., 42 (1972) 241-255.

[88] N.A. Clinton, J.K. Kochi, J. Organometal. Chem., 56 (1973) 243-254.

[89] N. Navon, G. Golub, H. Cohen, D. Meyerstein, Organometallics, 14 (1995) 5670-5676.

[90] M. Freiberg, W.A. Mulac, K.H. Schmidt, D. Meyerstein, Journal of the Chemical Society-

Faraday Transactions I, 76 (1980) 1838-1848.

[91] H. Cohen, D. Meyerstein, Journal of the Chemical Society-Faraday Transactions I, 84 (1988) 4157-4160.

[92] Y. Sorek, H. Cohen, D. Meyerstein, Journal of the Chemical Society-Faraday Transactions I, 82 (1986) 3431-3438.

[93] H. Cohen, D. Meyerstein, Inorg. Chem., 26 (1987) 2342-2344.

[94] S. Das, G.R.A. Johnson, Journal of the Chemical Society-Faraday Transactions I, 76 (1980) 1779-1789.

[95] S. Das, G.R.A. Johnson, N.B. Nazhat, R. Saadalla-Nazhat, Journal of the Chemical SocietyFaraday Transactions I, 80 (1984) 2759-2766.

[96] M. Masarwa, H. Cohen, D. Meyerstein, Inorg. Chem., 30 (1991) 1849-1854.

[97] C. Arnoldi, A. Citterio, F. Minisci, Journal of the Chemical Society-Perkin Transactions 2, (1983) 531-541.

[98] S. Goldstein, G. Czapski, H. Cohen, D. Meyerstein, J.K. Cho, S.S. Shaik, Inorg. Chem., 31 (1992) 798-803.

[99] S. Goldstein, G. Czapski, H. Cohen, D. Meyerstein, Inorg. Chim. Acta, 192 (1992) 87-93.

[100] S. Goldstein, G. Czapski, H. Cohen, D. Meyerstein, Inorg. Chem., 27 (1988) 4130-4135.

[101] A. Szulc, D. Meyerstein, H. Cohen, Inorg. Chim. Acta, 270 (1998) 440-445.

[102] T.J. Zerk, P.V. Bernhardt, Inorg. Chem., 56 (2017) 5784-5792.

[103] A.A. Gridnev, S.D. Ittel, Chem. Rev., 101 (2001) 3611-3659.

[104] N. Soerensen, H. Schroeder, M. Buback, Macromolecules, 49 (2016) 4732-4738.

[105] T.G. Ribelli, L.D. Plath, C. Gayathri, M.E. Bier, R. Poli, K. Matyjaszewski, (in

preparation).

[106] D. Geiger, G. Ferraudi, Inorganica Chimica Acta-Articles and Letters, 101 (1985) 197-201.

[107] P.J. Chmielewski, L. Latos-Grazynski, I. Schmidt, Inorg. Chem., 39 (2000) 5475-5482.

[108] H. Furuta, H. Maeda, A. Osuka, Org. Lett., 4 (2002) 181-184.

[109] H. Furuta, T. Ishizuka, A. Osuka, Y. Uwatoko, Y. Ishikawa, Angew. Chem. Int. Ed., 40 (2001) 2323-2325.

[110] H. Maeda, A. Osuka, Y. Ishikawa, I. Aritome, Y. Hisaeda, H. Furuta, Org. Lett., 5 (2003) 1293-1296.

[111] N. Grzegorzek, M. Pawlicki, L. Szterenberg, L. Latos-Grazynski, J. Am. Chem. Soc., 131 (2009) 7224-7225.

[112] X.L. Hu, I. Castro-Rodriguez, K. Meyer, J. Am. Chem. Soc., 125 (2003) 12237-12245.

[113] A.O. Larsen, W. Leu, C.N. Oberhuber, J.E. Campbell, A.H. Hoveyda, J. Am. Chem. Soc., 126 (2004) 11130-11131.

[114] J.M. Smith, J.R. Long, Inorg. Chem., 49 (2010) 11223-11230.

[115] I. Kinoshita, L.J. Wright, S. Kubo, K. Kimura, A. Sakata, T. Yano, R. Miyamoto, T.

Nishioka, K. Isobe, Dalton Trans., (2003) 1993-2003. 
[116] R. Miyamoto, R. Santo, T. Matsushita, T. Nishioka, A. Ichimura, Y. Teki, I. Kinoshita, Dalton Trans., (2005) 3179-3186.

[117] R. Miyamoto, R.T. Hamazawa, M. Hirotsu, T. Nishioka, I. Kinoshita, L.J. Wright, Chem. Commun., (2005) 4047-4049.

[118] J. Tehranchi, P.J. Donoghue, C.J. Cramer, W.B. Tolman, Eur. J. Inorg. Chem., 2013 (2013) 4077-4084. 